\title{
Low pH Environmental Stress Inhibits LPS and LTA-Stimulated Proinflammatory Cytokine Production in Rat Alveolar Macrophages
}

\author{
Stanley F. Fernandez, ${ }^{1}$ Christopher Fung, ${ }^{2,3}$ Jadwiga D. Helinski, ${ }^{2,3}$ Ravi Alluri, ${ }^{2,3}$ \\ Bruce A. Davidson, ${ }^{2,3}$ and Paul R. Knight III $^{2,3}$ \\ ${ }^{1}$ Department of Medicine, Division of Cardiovascular Medicine, University at Buffalo, Suite 7030, 875 Ellicott Street, \\ Buffalo, NY 14203, USA \\ ${ }^{2}$ Department of Anesthesiology, University at Buffalo, 3435 Main Street, Buffalo, NY 14214, USA \\ ${ }^{3}$ Department of Microbiology, University at Buffalo, 3435 Main Street, Buffalo, NY 14214, USA
}

Correspondence should be addressed to Paul R. Knight III; pknight@buffalo.edu

Received 3 May 2013; Revised 12 July 2013; Accepted 17 July 2013

Academic Editor: Carlo Jose Freire de Oliveira

Copyright (C) 2013 Stanley F. Fernandez et al. This is an open access article distributed under the Creative Commons Attribution License, which permits unrestricted use, distribution, and reproduction in any medium, provided the original work is properly cited.

\begin{abstract}
Gastric aspiration increases the risks for developing secondary bacterial pneumonia. Cytokine elaboration through pathogen recognition receptors (PRRs) is an important mechanism in initiating innate immune host response. Effects of low $\mathrm{pH}$ stress, a critical component of aspiration pathogenesis, on the PRR pathways were examined, specifically toll-like receptor-2 (TLR2) and TLR4, using isolated rat alveolar macrophages (aMØs). We assessed the ability of aMØs after brief exposure to acidified saline to elaborate proinflammatory cytokines in response to lipopolysaccharide (LPS) and lipoteichoic acid (LTA) stimulation, known ligands of TLR4 and TLR2, respectively. Low $\mathrm{pH}$ stress reduced LPS- and LTA-mediated cytokine release (CINC-1, MIP-2, TNF$\alpha$, MCP-1, and IFN- $\beta$ ). LPS and LTA increased intracellular $\mathrm{Ca}^{2+}$ concentrations while $\mathrm{Ca}^{2+}$ chelation by BAPTA decreased LPSand LTA-mediated cytokine responses. BAPTA blocked the effects of low $\mathrm{pH}$ stress on most of LPS-stimulated cytokines but not of LTA-stimulated responses. In vivo mouse model demonstrates suppressed E. coli and S. pneumoniae clearance following acid aspiration. In conclusion, low $\mathrm{pH}$ stress inhibits antibacterial cytokine response of aMØs due to impaired TLR2 (MyD88 pathway) and TLR4 signaling (MyD88 and TRIF pathways). The role of $\mathrm{Ca}^{2+}$ in low $\mathrm{pH}$ stress-induced signaling is complex but appears to be distinct between LPS- and LTA-mediated responses.
\end{abstract}

\section{Introduction}

Gastric aspiration pneumonitis is a major cause of death and disability. An important complication of this acute lung injury is the development of a secondary pulmonary bacterial pneumonia from inhalation of oropharyngeal or gastric bacterial flora. Patients that are specifically susceptible to gastric aspiration pneumonitis are those with impaired airway defense reflexes such as anesthetized patients or patients with altered mental status. Consequences of low $\mathrm{pH}$ gastric aspiration can range from benign aseptic pneumonitis to acute respiratory distress syndrome (ARDS) with or without a fulminant secondary bacterial infection. It is estimated that complications from gastric aspirations can be seen in 1 of every 2,000-4,000 anesthetic cases every year and possibly $10-15 \%$ of all community acquired pneumonia $[1,2]$.

Common bacterial organisms implicated in aspiration pneumonia include Streptococcus pneumoniae, Staphylococcus aureus, Haemophilus influenzae, and Enterobacteriaceae [1]. Although gastric components are highly variable with varying proportions of gastric particles, acidity, and bacterial load, it appears that the extent of pulmonary injury is directly related to the aspirate volume, acidity, and composition [3, 4]. In rat models of gastric aspiration injury, intratracheal administration of acidified solution ( $\mathrm{pH}$ of 1.25) results in an early direct corrosive irritation to the airway epithelium 
followed by a delayed inflammatory response (4-6 hours after exposure) characterized by neutrophil activation and extravasation into the air spaces and elaboration of proinflammatory mediators and chemotactic cytokines $[3,5,6]$. Gastric aspiration is an important risk factor for bacterial pneumonia [7]. Using an in vivo rat model, our laboratory has demonstrated that a preceding gastric aspiration injury results in reduced clearance of Escherichia coli instilled into the lungs [7]. The mechanism by which transient pulmonary low $\mathrm{pH}$ stress promotes bacterial infection is the focus of this investigation.

Our major hypothesis is that a transient low $\mathrm{pH}$ environment resulting from gastric aspiration adversely affects alveolar macrophage (aMØ) antimicrobial function. Using isolated rat aMØs, we investigated the effects of a transient low $\mathrm{pH}$ exposure in impairing the ability of these cells to express cytokines in response to ligation of pathogen recognition receptors (PRRs). Macrophages were stimulated, in vitro, with the pathogen associated molecular pattern (PAMP) ligands of E. coli lipopolysaccharide (LPS) or pneumococcal lipoteichoic acid (LTA), known ligands of toll-like receptor (TLR) 4 and TLR2, respectively. TLRs are PRRs utilized by immune sentinel cells to recognize microbial PAMPs to illicit antibacterial proinflammatory responses [8]. The aMØs' response to receptor ligation was quantified based on protein levels of cytokine-induced neutrophil chemoattractant1 (CINC-1), macrophage inflammatory protein-2 (MIP-2), tumor necrosis factor- $\alpha$ (TNF- $\alpha$ ), macrophage chemoattractant protein-1 (MCP-1), and interferon- $\beta$ (IFN- $\beta$ ) in the culture supernatant, as assessed by ELISA. The role of cytosolic $\mathrm{Ca}^{2+}$ in mediating the effects of low $\mathrm{pH}$ stress was also investigated $[9,10]$ using the $\mathrm{Ca}^{2+}$-sensitive dye, Fura-2, in single cell imaging studies or the $\mathrm{Ca}^{2+}$ chelator, BAPTA, in cell culture stimulation studies. These findings will help identify the mechanisms by which gastric aspiration can alter $\mathrm{M} \varnothing$ function and modify innate immune responses that may predispose patients to secondary pulmonary bacterial infections.

\section{Materials and Methods}

2.1. Rat Alveolar Macrophage Isolation. Bronchoalveolar lavage (BAL) was performed on naïve Long-Evans rats (Harlan Sprague-Dawley, Indianapolis, IN) weighing 250-390 g to isolate alveolar macrophages for in vitro experiments. Briefly, rats were anesthetized with $2-3 \%$ halothane in $100 \% \mathrm{O}_{2}$ to full anesthetic effect and then exsanguinated by transecting the inferior vena cava. After thoracotomy, the thoracic and pulmonary vasculatures were flushed using $20 \mathrm{~mL}$ of Hank's balanced salt solution with $\mathrm{Ca}^{2+}$ and $\mathrm{Mg}^{2+}$ (HBSS) injected directly into the right ventricle. A 14-gauge catheter was inserted and secured in the trachea and BAL performed with $50 \mathrm{~mL}$ of normal saline instilled in $10 \mathrm{~mL}$ aliquots. The instilled saline solution was recovered and kept in ice until processing.

2.2. Cell Plating. The recovered BAL fluid was centrifuged at $1,500 \times \mathrm{g}$ for $3 \mathrm{~min}$ at $4^{\circ} \mathrm{C}$ and the cell-free supernatant discarded. The cell pellet was resuspended in $4 \mathrm{~mL}$ of culture media (RPMI-1640, Life Technologies, Carlsbad, CA), containing $10 \%$ heat-inactivated fetal calf serum and penicillin and streptomycin. A cytoslide was prepared with $5 \times 10^{4}$ cells plated onto a slide and centrifuged at $28 \times \mathrm{g}$ (Cytospin 3 cytocentrifuge, Shandon, Pittsburgh, PA) for $5 \mathrm{~min}$, air dried, and stained with Diff-Quik (Dade Behring, Newark, DE). Microscopic assessment demonstrated that plated cells were $\geq 98 \%$ macrophages. Alveolar macrophages were $>95 \%$ viable prior to plating as determined by Trypan Blue exclusion. Cells were resuspended in warm culture media and seeded in polyL-lysine-coated 24-well polystyrene tissue culture plates at a density of $2 \times 10^{5}$ cells/well, $500 \mu \mathrm{L} /$ well for ELISA studies, or $200 \mu \mathrm{L} /$ well in 96-well plates for WST-1 cell viability (Roche Diagnostics, Indianapolis, IN) studies. Cells were incubated at $37^{\circ} \mathrm{C}, 95 \% \mathrm{RH}$, and $5 \% \mathrm{CO}_{2}$ (all incubations were performed under these conditions unless otherwise noted) for 20-22 hrs to allow cells to attach and quiesce.

2.3. Treatment Conditions. Plated cells were washed with an unbuffered balanced salt solution (UBSS, $144 \mathrm{mM} \mathrm{NaCl}$, $5.4 \mathrm{mM} \mathrm{KCl}, 1.8 \mathrm{mM} \mathrm{CaCl}_{2}$, and $0.8 \mathrm{mM} \mathrm{MgCl}_{2}$ ); then $100 \mu \mathrm{L} /$ well of appropriate injury solution, UBSS (uninjured control) or UBSS $+1 \mathrm{~N} \mathrm{HCl}, \mathrm{pH}=1.75$ (acidic injury), was added to each well. After $1 \mathrm{~min}$ of injury exposure, $400 \mu \mathrm{L}$ of culture media was added (neutralizing the injury solution) and then removed and replaced with $500 \mu \mathrm{L} /$ well fresh culture media containing $1.5 \mu \mathrm{g} / \mathrm{mL}$ LPS, $30 \mu \mathrm{g} / \mathrm{mL}$ LTA, or media alone (nonstimulated control). The cultures were incubated, as above, for $24 \mathrm{hrs}$ and the supernatant collected and stored at $-80^{\circ} \mathrm{C}$ for subsequent analysis. $\mathrm{A} \mathrm{pH}=1.75$ was specifically chosen to represent the most acidic injury that did not cause significant reduction in macrophage viability. This was based on a study examining a $1 \mathrm{~min}$ exposure to a range of $\mathrm{pH}$ from 1.25 to 3.00 using a WST-1 cell viability assay (Roche Diagnostics, Indianapolis, IN), a colorimetric measure of cellular metabolic activity. Incubation with $\mathrm{pH} 1.75$ for $1 \mathrm{~min}$ was established as the most appropriate $\mathrm{pH}$ to maximize low $\mathrm{pH}$ injury without producing cell death. For intracellular calcium sequestration experiments, macrophages were incubated with $5 \mu \mathrm{M}$ BAPTA-AM (an intracellular $\mathrm{Ca}^{2+}$ chelator) in culture media (Life Technologies, Grand Island, NY) for 30 min prior to initiating the acidic injury and LPS or LTA stimulation procedures.

2.4. Cytokine Analysis. Cell-free culture media were analyzed by ELISA to determine concentrations of CINC-1, MIP-2, and MCP-1 using their respective antibody pairs and recombinant protein standards from R\&D Systems (Minneapolis, MN) and IFN- $\beta$ from USCN Life Sciences (Houston, TX), as previously described [11]. TNF- $\alpha$ levels were assessed by cytotoxicity bioassay using WEHI 164, subclone 13 cells (a generous gift from Dr. Steven L. Kunkel, Department of Michigan, Ann Arbor, MI). This cell line is a TNF- $\alpha$ sensitive line derived from a mouse fibrosarcoma which allows assessment of bioactive TNF- $\alpha$ as previously described [11]. 
2.5. Fluorescence Calcium Imaging. Freshly isolated alveolar macrophages $\left(2 \times 10^{5}\right.$ cells in $200 \mu \mathrm{L}$ culture media) were dispensed into the $10 \mathrm{~mm}$ diameter microwell in the middle of a $35 \mathrm{~mm}$ diameter glass bottom plastic culture dish with a poly-L-lysine-coated no. 1.5 glass coverslip defining the well bottom (MatTek Corp., Ashland, MA). The cells were incubated for $2 \mathrm{hrs}$ to allow cell attachment. An additional $2 \mathrm{~mL}$ of culture medium was added, and the cells were incubated for 20-22 hrs. The in vitro injury procedure described above (UBSS $+\mathrm{HCl}, \mathrm{pH}=1.75$ for $1 \mathrm{~min}$ ) was performed, the cells washed, and culture media containing $1.5 \mu \mathrm{g} / \mathrm{mL}$ LPS or $30 \mu \mathrm{g} / \mathrm{mL}$ LTA added. Following the appropriate duration of incubation, the cells were washed $2 \mathrm{x}$ with Buffer A $\left(124 \mathrm{mM} \mathrm{NaCl}, 5.8 \mathrm{mM} \mathrm{KCl}, 1.4 \mathrm{mM} \mathrm{KH}_{2} \mathrm{PO}_{4}, 18.7 \mathrm{mM}\right.$ HEPES, $14.1 \mathrm{mM}$ dextrose, $0.68 \mathrm{mM}$ mannitol, and $1.8 \mathrm{mM}$ $\left.\mathrm{CaCl}_{2}, \mathrm{pH}=7.4\right)$ and then incubated with $6 \mu \mathrm{g} / \mathrm{mL}$ Fura-2 AM (Life Technologies, Grand Island, NY) for $30 \mathrm{~min}$. The cells were then washed twice with Buffer A and incubated for an additional $15 \mathrm{~min}$ in Buffer A to allow the Fura-2 AM to deesterfy. The culture dish was placed on an inverted microscope stage of a dual-excitation microscopic fluorescence spectrophotometer (Photon Technology International, Birmingham, NJ) that was used to excite the dye at 340 and $380 \mathrm{~nm}$, alternating at a $2 \mathrm{~Hz}$ sampling rate. Fluorescence emissions at $510 \mathrm{~nm}$ were recorded as an excitation fluorescence ratio $\left(R_{340 / 380}\right.$, which is directly proportional to the intracellular calcium concentration, $\left[\mathrm{Ca}^{2+}\right]_{\mathrm{i}}$ ) by a digital PMT detector that was masked to allow emission measurements from a single alveolar macrophage. Measurements were taken for one minute on 10 different cells for each time point. For the immediate and $30 \mathrm{~min}$ time points, the cells were loaded with Fura-2 AM prior to low $\mathrm{pH}$ and LPS or LTA exposure.

2.6. Mouse Acid Aspiration Injury Model. Eight-week-old CD-1 male mice (Charles River Laboratories, Wilmington, MA) were used for in vivo experiments to determine the effects of low $\mathrm{pH}$ injury on bacterial clearance. After induction of halothane anesthesia, a tracheotomy was performed by midline incision and blunt dissection. A 22 ga needle was inserted into the trachea under direct visualization, and $3.6 \mathrm{~mL} / \mathrm{kg}$ normal saline, $\mathrm{pH}=5.3(\mathrm{NS})$, or $\mathrm{NS}+$ $\mathrm{HCl}, \mathrm{pH}=1.25$, (Acid) was injected followed by a $0.2 \mathrm{~mL}$ bolus of air while the mouse was suspended by its incisors in a $60^{\circ}$ supine position. The bacterial challenge inoculum, $50 \mu \mathrm{L}$, was instilled through the same needle $1 \mathrm{~min}$ following the NS or Acid instillation. Two separate bacterial inocula were prepared, Escherichia coli (E. coli, CP9, an extraintestinal pathogenic E. coli strain) and Streptococcus pneumoniae (S. pneumoniae, strain: EF3030). E. coli was prepared by culturing overnight at $37^{\circ} \mathrm{C}$ in LuriaBertani medium and centrifuged at $8,000 \times \mathrm{g}$ for $4 \mathrm{~min}$ at $4^{\circ} \mathrm{C}$ and then resuspending the pellet in sterile NS to $5 \times$ $10^{6}$ colony-forming units (cfu) $/ 50 \mu$ L. S. pneumonia cultures were prepared from frozen stocks of known titer that were centrifuged as above and the pellet resuspended in sterile NS to $5 \times 10^{5} \mathrm{cfu} / 50 \mu \mathrm{L}$. Actual inocula titers were determined by serial titration just prior to each in vivo injury experiment. Mice were sacrificed at $24 \mathrm{hrs}$ after intratracheal challenge by exsanguination during halothane anesthesia. Lungs were removed and homogenized by adding sterile lung homogenate buffer, $\mathrm{pH}=7.4(150 \mathrm{mM} \mathrm{NaCl}, 15 \mathrm{mM}$ Tris base, $1 \mathrm{mM} \mathrm{CaCl} \cdot 2 \mathrm{H}_{2} \mathrm{O}, 1 \mathrm{mM} \mathrm{MgCl} 2 \cdot 6 \mathrm{H}_{2} \mathrm{O}$ containing $500 \mu \mathrm{M}$ AEBSF $\mathrm{HCl}, 150 \mathrm{nM}$ aprotinin, $1 \mu \mathrm{M}$ E-64, $0.5 \mathrm{mM}$ disodium EDTA, and $1 \mu \mathrm{M}$ leupeptin hemisulfate) (protease inhibitor cocktail set I, Calbiochem/EMD Chemicals, Gibbstown, NJ), such that the total lung plus buffer weight was $3 \mathrm{~g}$ (i.e., $3 \mathrm{~mL}$ ) and homogenizing on ice with a Polytron PT2000 tissue homogenizer (Brinkman Instruments, Westbury, $\mathrm{NY})$. Bacterial titer $(\mathrm{cfu} / \mathrm{mL})$ of the homogenized tissue was determined by serial titration and the bacterial load determined by multiplying the lung homogenate titer by the total volume (i.e., $3 \mathrm{~mL}$ ). Bacterial clearance was expressed as $\log _{10}$ (starting inoculum/lung homogenate bacterial load at time of harvest). All procedures performed on animals were approved by the Institutional Animal Care and Use Committee at the University at Buffalo and complied with all state, federal, and National Institutes of Health regulations.

2.7. Statistical Analysis. All data are expressed as mean \pm SEM. Statistical analyses were performed using one-way ANOVA for multiple group analysis and two-tailed Student's $t$-test for direct group comparisons with $P<0.05$ considered as significant.

\section{Results}

3.1. Effects of Low pH Stress on LPS-Induced Cytokine Production in Alveolar Macrophages. Bacterial LPS is an important structural lipoprotein found in Gram-negative bacteria that acts as a major activator of the antibacterial innate immune response. LPS ligates TLR4 to initiate intracellular signaling that results in production of antibacterial proinflammatory cytokines $[12,13]$. Isolated rat aMØs were stimulated with LPS $(1.5 \mu \mathrm{g} / \mathrm{mL}$ for $24 \mathrm{hrs})$, and production of CINC-1, MIP2 , TNF- $\alpha$, and MCP-1 was quantified (Figures $1(\mathrm{a})-1(\mathrm{~d})$ ). LPS significantly increased the production of CINC-1 from control levels of $153 \pm 43$ to $2944 \pm 224 \mathrm{pg} / \mathrm{mL}(P<0.001)$, MIP-2 from $250 \pm 66$ to $4347 \pm 319 \mathrm{pg} / \mathrm{mL}(P<0.001)$, TNF$\alpha$ from $23 \pm 10$ to $462 \pm 136 \mathrm{pg} / \mathrm{mL}(P=0.01)$, and MCP-1 from $160 \pm 28$ to $2009 \pm 172 \mathrm{pg} / \mathrm{mL}(P<0.001)$.

To investigate the effects of low $\mathrm{pH}$ stress on LPSstimulated cytokine profile, LPS-treated aMØs were first exposed to low $\mathrm{pH}$ stress (acidified saline at $\mathrm{pH} 1.75$ for $1 \mathrm{~min}$ ). This regimen of transient low $\mathrm{pH}$ exposure was specifically determined to allow maximal acid exposure without decreasing cell viability (see Section 2). This exposure protocol also mimics the transient gastric acid exposure that is rapidly neutralized in vivo. Following low $\mathrm{pH}$ stress, LPS-induced cytokine release was significantly blunted compared with LPS alone (Figure 1); CINC-1 was reduced by $58 \%(P<0.001)$, MIP-2 by $50 \%(P<0.005)$, TNF- $\alpha$ by $53 \%(P<0.05)$, and MCP-1 by $83 \%(P<0.001)$.

LPS ligation of TLR4 signals two distinct cytosolic pathways, the MyD88 pathway and the TRIF (MyD88 independent) pathway. MyD88 signaling increases production of CINC-1, MIP-2, TNF- $\alpha$, and MCP-1 through activation of 


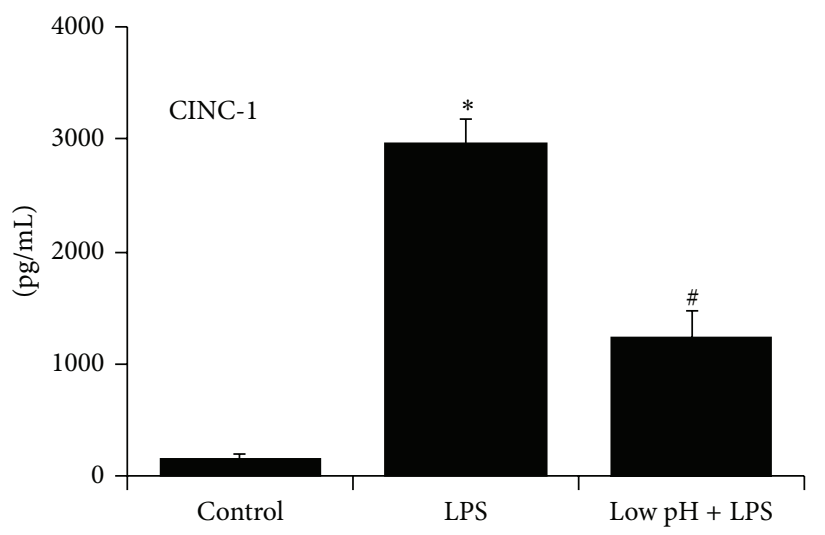

(a)

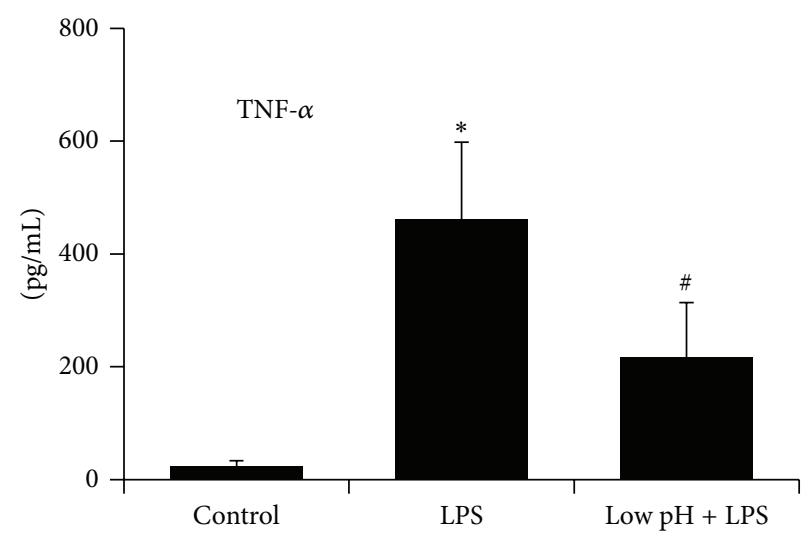

(c)

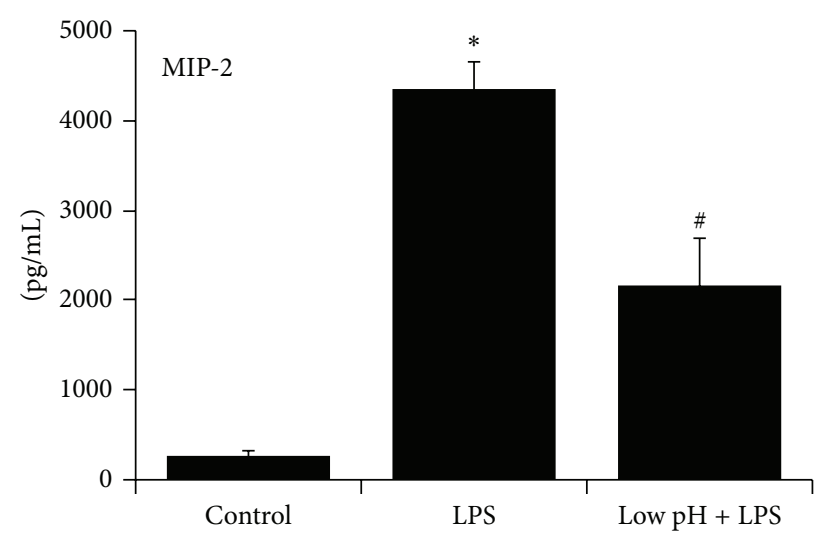

(b)

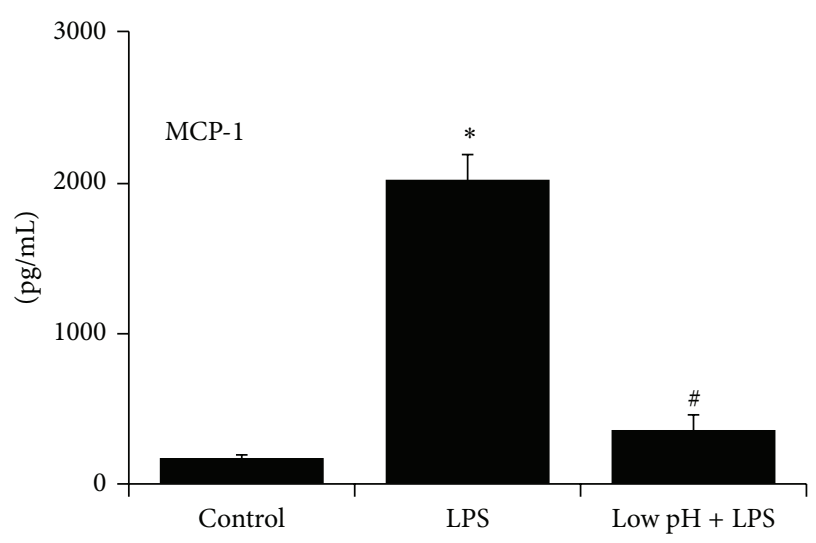

(d)

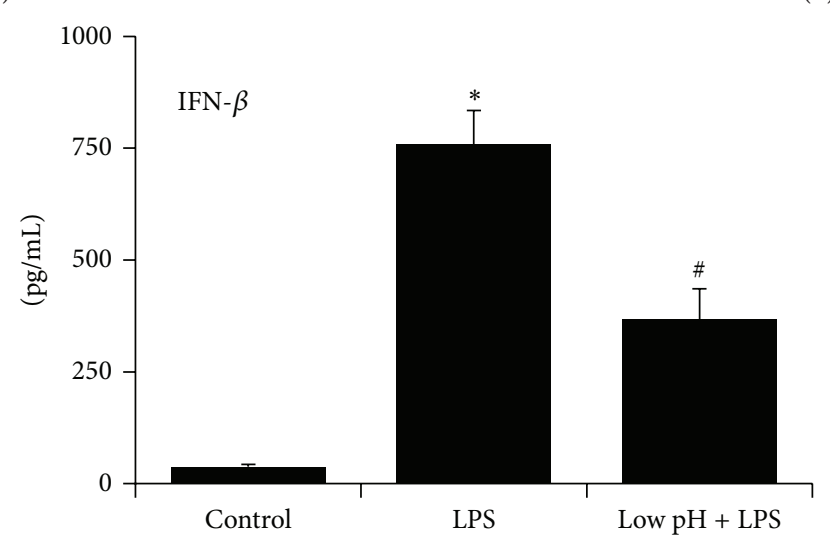

(e)

FIGURE 1: Effects of low $\mathrm{pH}$ stress on LPS-stimulated cytokine production in rat alveolar macrophages (aMØs). Isolated aMØs were stimulated in vitro with either saline (control), LPS alone $(1.5 \mu \mathrm{g} / \mathrm{mL}$ for $24 \mathrm{hrs})$, or LPS in combination with a preceding transient low pH stress injury ( $\mathrm{pH} 1.75$ for $1 \mathrm{~min}$, Low $\mathrm{pH}+\mathrm{LPS}$ ). Cytokines produced were assessed by ELISA (CINC-1, MIP-2, MCP-1, and INF- $\beta$ ) or cytotoxicity bioassay (TNF- $\alpha) .{ }^{*} P<0.05$ LPS versus control, ${ }^{\#} P<0.05$ LPS versus Low $\mathrm{pH}+\mathrm{LPS}$.

the transcription factor, NF- $\kappa \mathrm{B}$, while TRIF signaling increases IFN- $\beta$ production through activation of interferon regulatory transcription factor 3 (IRF3). To evaluate the involvement of the TRIF pathway, aMØs were stimulated with LPS for $24 \mathrm{hrs}$, and the release of IFN- $\beta$ was quantified using ELISA (see Section 2). LPS stimulation resulted in a significant increase in IFN- $\beta$ production from control levels of $37.8 \pm 5.8 \mathrm{pg} / \mathrm{mL}$ to $758.7 \pm 75.4 \mathrm{pg} / \mathrm{mL}(P<0.001$,
Figure 1(e)). Exposure to low $\mathrm{pH}$ stress reduced LPS-induced IFN $-\beta$ production by $52 \%(P<0.01)$. These findings suggest that low $\mathrm{pH}$ stress inhibits LPS-induced cytokine release through inhibition of both MyD88 and TRIF pathways.

3.2. Effects of Low pH Stress on LTA-Induced Cytokine Production in Alveolar Macrophages. The PAMP, LTA, is a major component of the outer cell wall of Gram-positive bacteria, 


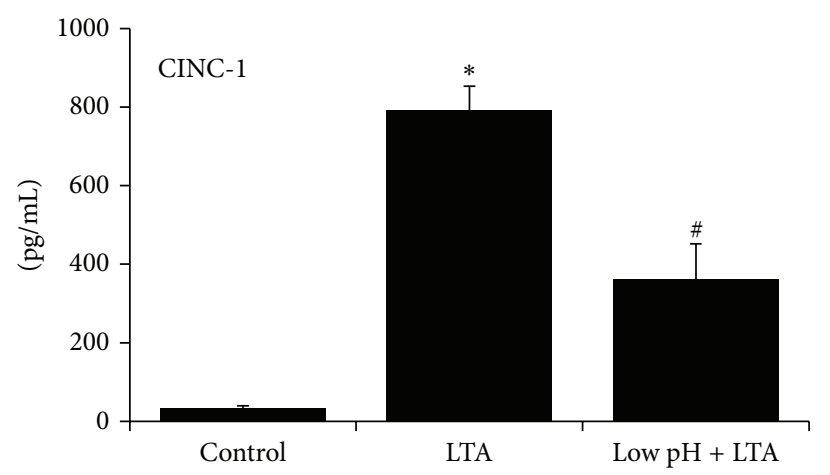

(a)

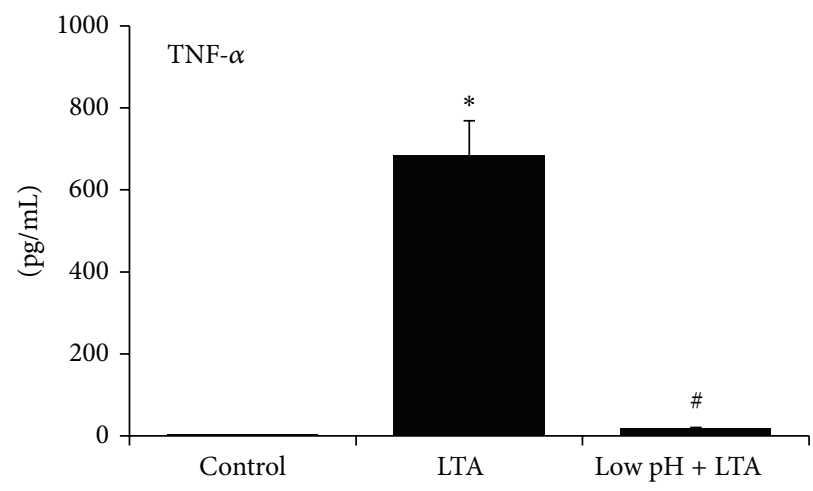

(c)

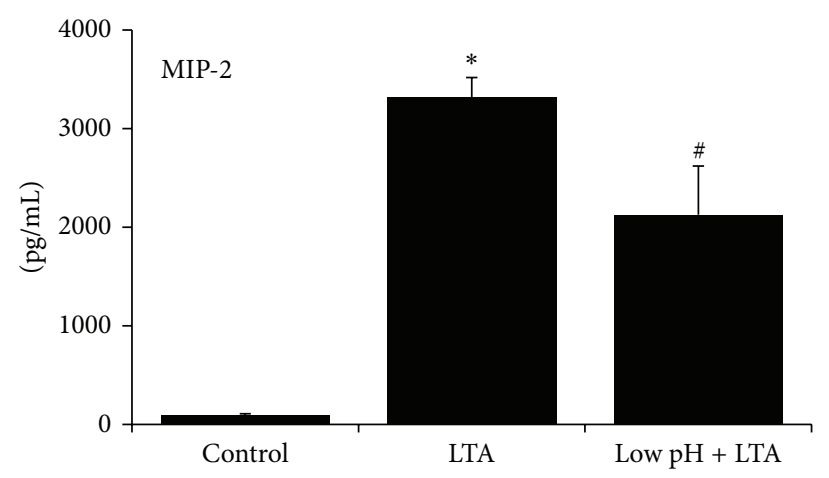

(b)

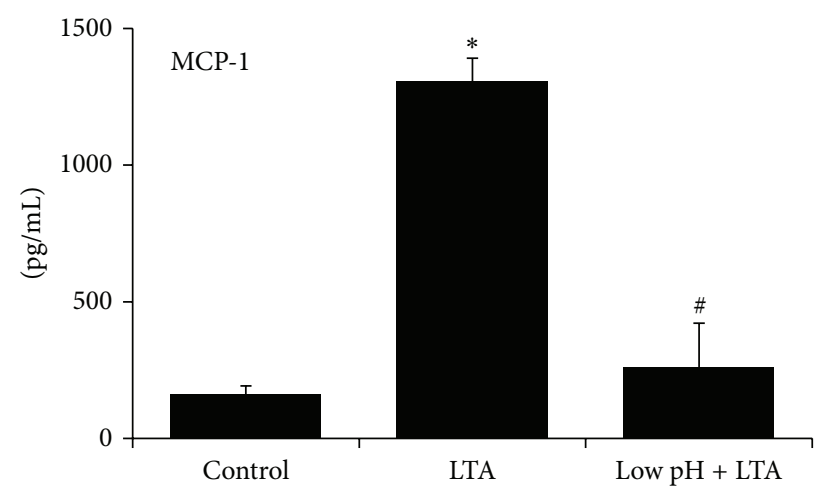

(d)

FIGURE 2: Effects of low pH stress on LTA-stimulated cytokine production in rat aMØs. Isolated aMØs were stimulated in vitro with either saline (control), LTA alone $(30 \mathrm{mg} / \mathrm{mL}$ for $24 \mathrm{hrs}$ ), or LTA in combination with a preceding transient low $\mathrm{pH}$ stress injury (pH $1.75 \mathrm{for} 1 \mathrm{~min}$, Low $\mathrm{pH}+\mathrm{LTA}$ ). Cytokines produced were assessed by ELISA (CINC-1, MIP-2, and MCP-1) or cytotoxicity bioassay $(\mathrm{TNF}-\alpha)$. ${ }^{*} \mathrm{P}<0.05$ LTA versus control, ${ }^{\#} P<0.05$ LTA versus Low $\mathrm{pH}+$ LTA.

and it shares many similarities with LPS in its proinflammatory effects. Cellular recognition of LTA is mediated by TLR2 ligation, which initiates cytosolic signaling that results in production of antibacterial cytokines [14, 15]. Isolated aMØs were stimulated in vitro with LTA $(30 \mathrm{mg} / \mathrm{mL}$ for $24 \mathrm{hrs}$ ), and production of CINC-1, MIP-2, TNF- $\alpha$, and MCP1 was quantified (Figure 2). LTA increased the production of CINC-1 from control levels of $33 \pm 5$ to $792 \pm 61 \mathrm{pg} / \mathrm{mL}(P<$ $0.001)$, MIP-2 from $99 \pm 9$ to $3316 \pm 200 \mathrm{pg} / \mathrm{mL}(P<0.001)$, TNF- $\alpha$ from $0.3 \pm 0.04$ to $685 \pm 83 \mathrm{pg} / \mathrm{mL}(P<0.001)$, and MCP-1 from $162 \pm 29$ to $1307 \pm 84 \mathrm{pg} / \mathrm{mL}(P<0.001)$.

To examine low $\mathrm{pH}$ stress on LTA-stimulated cytokines, aMØs were exposed to low $\mathrm{pH}$ stress (acidified saline at $\mathrm{pH} 1.75$ for $1 \mathrm{~min}$ ) prior to stimulation with LTA. Following low $\mathrm{pH}$ stress, LTA-induced cytokine production was significantly decreased compared to LTA alone (Figure 2); CINC-1 was reduced by $54 \%(P<0.05)$, MIP-2 by $35 \%(P=0.02)$, TNF- $\alpha$ by $97 \%(P=0.02)$, and MCP-1 by $80 \%(P<0.001)$.

3.3. Role of Intracellular $\mathrm{Ca}^{2+}$ in Mediating Effects of Low $\mathrm{pH}$ Stress on LPS-Stimulated Responses. Intracellular $\mathrm{Ca}^{2+}$ concentration $\left(\left[\mathrm{Ca}^{2+}\right]_{\mathrm{i}}\right)$ is an important regulator of macrophage function $[16-18]$. To assess the role of $\left[\mathrm{Ca}^{2+}\right]_{\mathrm{i}}$ in mediating the effects of low $\mathrm{pH}$ stress on LPS-mediated responses, changes in $\left[\mathrm{Ca}^{2+}\right]_{\mathrm{i}}$ were determined using the $\mathrm{Ca}^{2+}$-sensitive fluorescent dye, Fura-2 AM (see Section 2). AMØs were exposed transiently to low $\mathrm{pH}$ stress and subsequently stimulated with LPS for $24 \mathrm{hrs}$. Fluorescence intensities $\left(R_{340 / 380}\right)$ were measured at different time intervals within this $24 \mathrm{hr}$ period to identify variations in the temporal $\mathrm{Ca}^{2+}$ levels: immediate postexposure to LPS, after $30 \mathrm{~min}, 1 \mathrm{hr}, 4 \mathrm{hrs}$, and $24 \mathrm{hrs}$ of LPS exposure.

First, changes in $\left[\mathrm{Ca}^{2+}\right]_{\mathrm{i}}$ due to low $\mathrm{pH}$ stress alone were assessed. Low $\mathrm{pH}$ stress increased $R_{340 / 380}$, correlating with increased $\left[\mathrm{Ca}^{2+}\right]_{\mathrm{i}}$, in a biphasic pattern (Figure $3(\mathrm{a})$ ), increasing from a baseline value of $0.42 \pm 0.01$ to $1.04 \pm 0.06$, $P<0.001$. This increase in $\left[\mathrm{Ca}^{2+}\right]_{\mathrm{i}}$ persisted to the $30 \mathrm{~min}$ time point. At $1 \mathrm{hr}$ after low-pH exposure, the ratio dropped to baseline levels $\left(R_{340 / 380}=0.42 \pm 0.01, P=n s\right)$. This was followed by another rise in $R_{340 / 380}$ at $4 \mathrm{hrs}$ and $24 \mathrm{hrs}$ after exposure $\left(R_{340 / 380}\right.$ of $1.09 \pm 0.03, P<0.001$ and $0.96 \pm 0.05$, $P<0.001$, resp.).

We then examined the effects of LPS alone on $\left[\mathrm{Ca}^{2+}\right]_{i}$. Changes in $\left[\mathrm{Ca}^{2+}\right]_{i}$ were assessed at increasing duration of LPS incubation as described earlier. $R_{340 / 380}$ increased immediately following LPS stimulation from control levels of $0.77 \pm 0.01$ to $1.04 \pm 0.06(P=0.02)$ (Figure $3(\mathrm{~b}))$. The elevation was short-lived with return to baseline levels at both $30 \mathrm{~min}$ and $1 \mathrm{hr}$. This was followed by low levels of $\left[\mathrm{Ca}^{2+}\right]_{\mathrm{i}}$ at $4 \mathrm{hrs}$ and $24 \mathrm{hrs}$.

The effect of low $\mathrm{pH}$ stress on the LPS-mediated $\left[\mathrm{Ca}^{2+}\right]_{\mathrm{i}}$ profile was then investigated. AM $\varnothing$ s exposed to a transient 


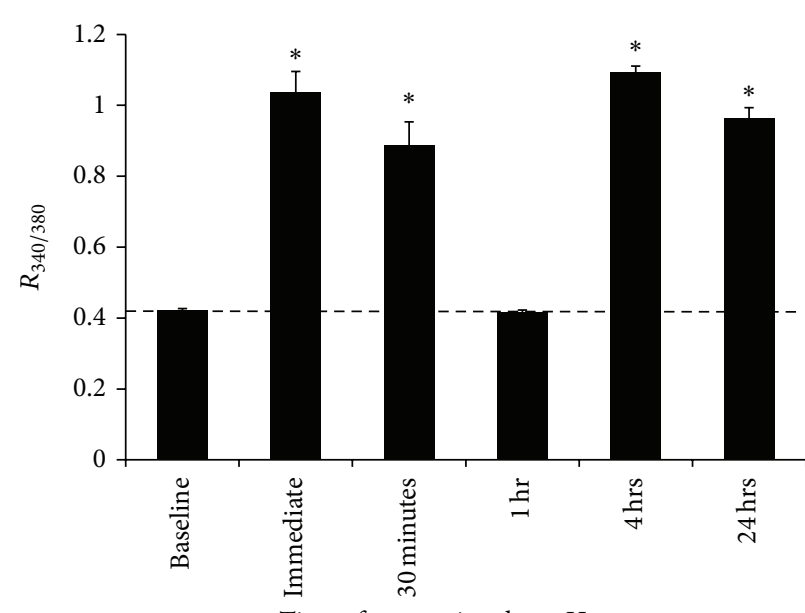

Time after transient low $\mathrm{pH}$ stress

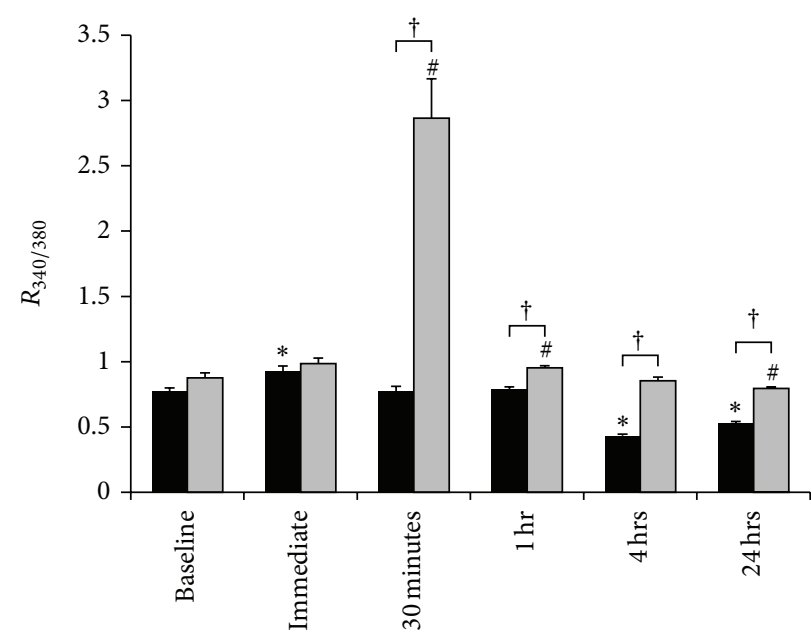

LPS incubation

LPS

$\square$ Low $\mathrm{pH}+\mathrm{LPS}$

(b)

(a)

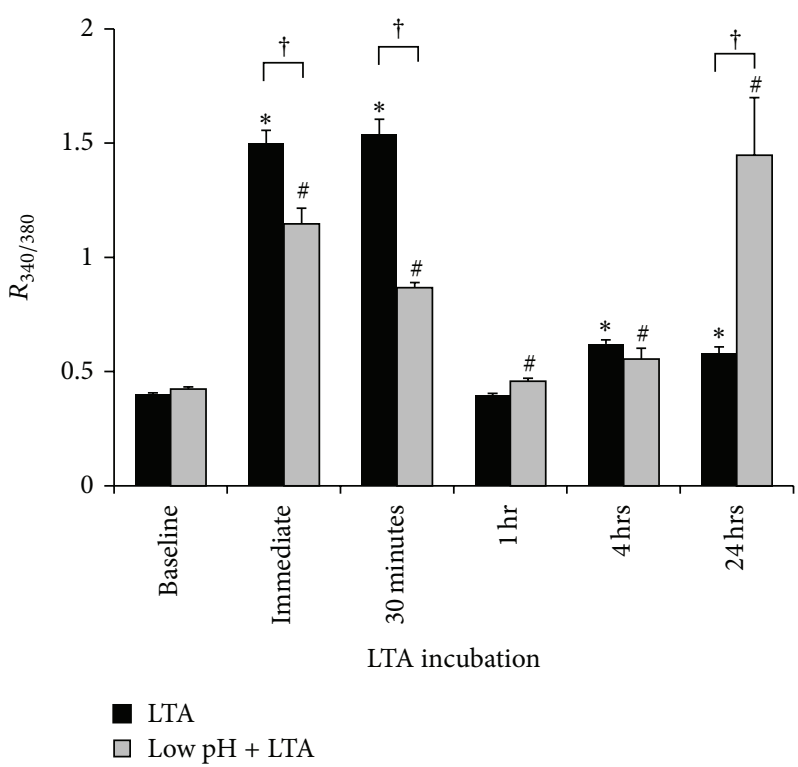

(c)

FIgURE 3: Intracellular $\mathrm{Ca}^{2+}$ concentration profile under various conditions, expressed as fluorescence excitation ratios $\left(R_{340 / 380}\right.$, proportional to $\left[\mathrm{Ca}^{2+}\right]_{\mathrm{i}}$ ) in Fura-2 AM-loaded aMØs. (a) Isolated aMØs loaded with Fura-2 AM were exposed to low pH stress in vitro and fluorescence ratios recorded at the indicated time points following low $\mathrm{pH}$ injury. (b) Fura-2 AM-loaded aMØs were stimulated with either LPS alone (black bar) or LPS preceded by transient low $\mathrm{pH}$ stress injury (Low $\mathrm{pH}+$ LPS, gray bar). (c) Fura-2 AM-loaded aMØs were stimulated with either LTA alone (black bar) or LTA stimulation preceded by a transient low $\mathrm{pH}$ stress injury (Low $\mathrm{pH}+\mathrm{LTA}$, gray bar). ${ }^{* / \#} P<0.05$ versus corresponding baseline, ${ }^{\dagger} \mathrm{P}<0.05$ presence of low $\mathrm{pH}$ stress versus absence of low $\mathrm{pH}$ stress.

low $\mathrm{pH}$ stress prior to LPS stimulation resulted in increased $\left[\mathrm{Ca}^{2+}\right]_{\mathrm{i}}$ at $30 \mathrm{~min}$ after LPS exposure (Figure $\left.3(\mathrm{~b})\right), 0.89 \pm$ 0.04 for LPS alone versus $2.86 \pm 0.30$ for low $\mathrm{pH} / \mathrm{LPS}(P<$ $0.001)$. The increased $R_{340 / 380}$ persisted at the $1 \mathrm{hr}(P<0.001)$, 4 hrs $(P<0.001)$, and 24 hrs LPS exposure times $(P<0.001)$.

3.4. Role of Intracellular $\mathrm{Ca}^{2+}$ in Mediating Effects of Low pH Stress on LTA-Stimulated Responses. To examine the role of $\left[\mathrm{Ca}^{2+}\right]_{\mathrm{i}}$ in mediating the effects of low $\mathrm{pH}$ stress on LTA-mediated responses, we identified changes in $\left[\mathrm{Ca}^{2+}\right]_{i}$ in response to LTA alone and following combined low $\mathrm{pH}$ stress and LTA stimulation (Figure 3(c)). In Fura-2 AM-loaded aMØs, LTA stimulation significantly increased $R_{340 / 380}$ from baseline levels of $0.40 \pm 0.00$ to $1.50 \pm 0.06(P<0.001)$. This elevation persisted at $30 \mathrm{~min}$ and returned to baseline levels at $1 \mathrm{hr}\left(R_{340 / 380}=0.40 \pm 0.01, P=\mathrm{ns}\right)$. After an initial return 
to baseline levels, the $R_{340 / 380}$ ratio developed a second wave of increased $\left[\mathrm{Ca}^{2+}\right]_{\mathrm{i}}$ at $4 \mathrm{hrs}$ and $24 \mathrm{hrs}, 0.62 \pm 0.02(P<0.001$ versus baseline) and $0.58 \pm 0.03(P<0.001)$, respectively.

The effect of low $\mathrm{pH}$ stress on LTA-induced $\mathrm{Ca}^{2+}$ profile was then investigated. LTA-stimulated aMØs were exposed to low $\mathrm{pH}$ conditions and changes in $R_{340 / 380}$ monitored. There was immediate suppression by low $\mathrm{pH}$ stress on the LTAinduced $\left[\mathrm{Ca}^{2+}\right]_{\mathrm{i}}$ increase, $1.50 \pm 0.06$ (LTA) versus $1.15 \pm$ 0.07 (LTA/Low $\mathrm{pH}), P<0.01$, and the $\left[\mathrm{Ca}^{2+}\right]_{\mathrm{i}}$ suppression persisted at $30 \mathrm{~min}$ after LTA exposure. At $1 \mathrm{hr}$ and $4 \mathrm{hrs}$, there was no difference in the LTA-stimulated response, with or without low $\mathrm{pH}$ stress. At $24 \mathrm{hrs}$, low $\mathrm{pH}$ stress resulted in a robust increase in $R_{340 / 380}, 0.58 \pm 0.03$ (LTA) versus $1.45 \pm 0.25$ (LTA/Low $\mathrm{pH}), P<0.001$.

These findings indicate that complex changes in $\left[\mathrm{Ca}^{2+}\right]_{\mathrm{i}}$ are induced by LPS and LTA, and the effect of low $\mathrm{pH}$ stress on $\left[\mathrm{Ca}^{2+}\right]_{\mathrm{i}}$ appears unique to the specific ligand/TLR interaction. In LPS-stimulated cells, low $\mathrm{pH}$ stress resulted in low level augmentation of $\left[\mathrm{Ca}^{2+}\right]_{\mathrm{i}}$ while, in LTA-stimulated cells, low $\mathrm{pH}$ stress initially suppressed the $\left[\mathrm{Ca}^{2+}\right]_{\mathrm{i}}$ increase but was followed by a robust augmentation in $\left[\mathrm{Ca}^{2+}\right]_{\mathrm{i}}$.

3.5. Effects of Intracellular $\mathrm{Ca}^{2+}$ Sequestration on the Modulatory Role of Low pH Stress on LPS-Stimulated Cytokine Production. To further investigate the role of $\mathrm{Ca}^{2+}$ in LPS-stimulated aMØs, BAPTA-AM was utilized as a cell-permeable $\mathrm{Ca}^{2+}$ chelator to effectively sequester $\left[\mathrm{Ca}^{2+}\right]_{\mathrm{i}}[19]$. The general hypothesis is that if elevated $\left[\mathrm{Ca}^{2+}\right]_{\mathrm{i}}$ is necessary as an intermediate signal for LPS responses, BAPTA-AM will effectively inhibit these responses. AMØs were stimulated with LPS in the presence or absence of BAPTA-AM and cytokine production quantified. BAPTA-AM alone (control) did not result in any significant change in measured cytokines (Figure 4). In LPS stimulated cells, BAPTA-AM pretreatment decreased CINC-1 production by $64 \%(P<0.001)$, MIP-2 by $67 \%(P<$ $0.001)$, MCP-1 by 79\% $(P<0.001)$, and IFN- $\beta(P<0.001)$ from their LPS treatment levels. TNF- $\alpha$ levels trended down but were not statistically significant $(P=0.07)$.

It was subsequently tested whether low $\mathrm{pH}$ stress can further modulate cytokine production in $\mathrm{Ca}^{2+}$-chelated, LPSstimulated aMØs (Figure 5). Low $\mathrm{pH}$ stress did not affect CINC-1, MIP-2, MCP-1, and IFN- $\beta$ production in LPS/ BAPTA-AM-treated macrophages but significantly reduced TNF- $\alpha$ production by $82 \%(P<0.001)$.

3.6. Effects of Intracellular $\mathrm{Ca}^{2+}$ Sequestration on LTA-Mediated Cytokine Responses. A set of experiments were performed using LTA-stimulated aMØs with BAPTA-AM. BAPTA-AM, in LTA-stimulated macrophages (Figure 6), reduced levels of CINC-1 by $64 \%(P<0.001)$, MIP-2 by $53 \%(P<0.01)$, TNF- $\alpha$ by $65 \%(P<0.05)$, and MCP-1 by $51 \%(P<0.05)$, when compared with LTA treatment in the absence of BAPTA-AM. It was subsequently investigated whether low $\mathrm{pH}$ stress would further modulate cytokine production in $\mathrm{Ca}^{2+}$-chelated, LTA-stimulated aM $\varnothing$ s (Figure 7). Low $\mathrm{pH}$ stress suppressed levels of CINC-1 by $43 \%(P<0.001)$, MIP2 by $46 \%(P<0.01)$, and TNF- $\alpha$ by $82 \%(P<0.001)$ in LTA/BAPTA-AM-treated cells. Low $\mathrm{pH}$ stress tended to suppress MCP-1 $(P=0.06)$.

3.7. Effects of Low pH Stress on Bacterial Clearance In Vivo. To determine the effects of low $\mathrm{pH}$ stress on bacterial clearance in vivo, mice were exposed to an acidic pulmonary aspiration injury followed by intratracheal instillation of either $E$. coli or S. pneumoniae (mimicking LPS and LTA response, resp.) (see Section 2). In animals inoculated with $E$. coli, starting inoculum was $5.3 \times 10^{6} \pm 0.5 \times 10^{6} \mathrm{cfu}(n=17)$. Twentyfour hours after intratracheal $E$. coli challenge, resulting lung bacterial loads in the absence of low $\mathrm{pH}$ injury were $5.3 \times$ $10^{3} \pm 4.4 \times 10^{3} \mathrm{cfu}(n=13)$ versus $1.1 \times 10^{5} \pm 0.3 \times 10^{5} \mathrm{cfu}$ ( $n=17$ ) in the presence of low $\mathrm{pH}$ injury, demonstrating an increased $E$. coli load after low $\mathrm{pH}$ injury. Estimated E. coli clearance (see bacterial clearance estimation under Methods section) was $3.7 \pm 0.2$ versus $1.9 \pm 0.1$, respectively $(P<0.001)$. In animals inoculated with $S$. pneumoniae, starting inoculum was $4.5 \times 10^{5} \pm 0(n=5)$. Twenty-four hours after intratracheal $S$. pneumoniae challenge, resulting lung bacterial loads in the absence of low $\mathrm{pH}$ injury were $5.8 \times 10^{3} \pm 2.9 \times 10^{3} \mathrm{cfu}$ versus $8.4 \times 10^{7} \pm 3.1 \times 10^{7} \mathrm{cfu}$ in the presence of low $\mathrm{pH}$ injury, demonstrating a profound increase in total S. pneumoniae load, in excess of the starting inoculum. Estimated S. pneumoniae clearance was $2.4 \pm 0.4$ versus $-2.19 \pm 0.2$, respectively $(P<0.001)$.

\section{Discussion}

The innate immune system recognizes a wide variety of bacterial pathogens through a series of PRRs including TLRs, C-type lectin, and NOD-like receptors. The TLRs are the most widely studied PRRs with at least 10 recognized subtypes, each recognizing specific microbial patterns. In this study we examined TLR4- and TLR2-cytosolic signal transduction pathways through the use of LPS and LTA, respectively, to identify detrimental effects of nonlethal low $\mathrm{pH}$ stress on aM $\varnothing$ function. Clinical consequences of gastric aspiration are well established, ranging from a self-limiting aspiration pneumonitis to life threatening lung injury as seen in ARDS. Superimposed bacterial pneumonia is a frequent and deleterious sequela of gastric aspiration. In vivo animal studies have demonstrated that gastric acid aspiration results in a severe heterogeneous lung injury [20] which involves both direct low $\mathrm{pH}$ stress and indirect, non-pH stress-induced inflammation. This inflammatory response involves mechanisms that include direct tissue damage [11], impairment of surfactant function [20], and augmented recruitment of inflammatory/immune cells [11].

aMØs are sentinel cells that act as the initial line of defense against bacterial infection and are exposed to the inhaled fluid during a gastric aspirate event. This fluid often includes a low $\mathrm{pH}$ component, partially digested food particles, and potentially different degrees of bacterial loading arising from oropharyngeal and/or gastric colonization. The role of low $\mathrm{pH}$ stress in modulating aMØs function contributing to susceptibility to bacterial infection is not completely understood. Our group used an in vitro model to mimic low 


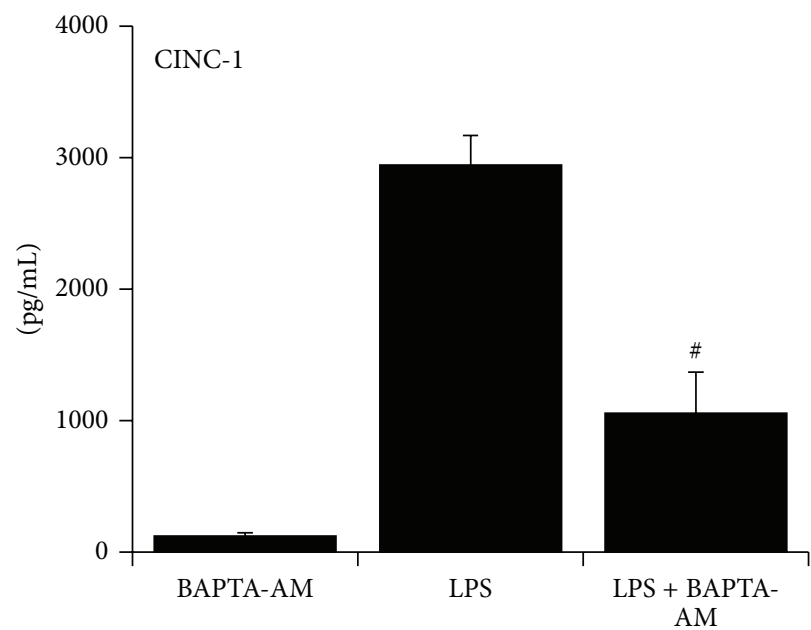

(a)

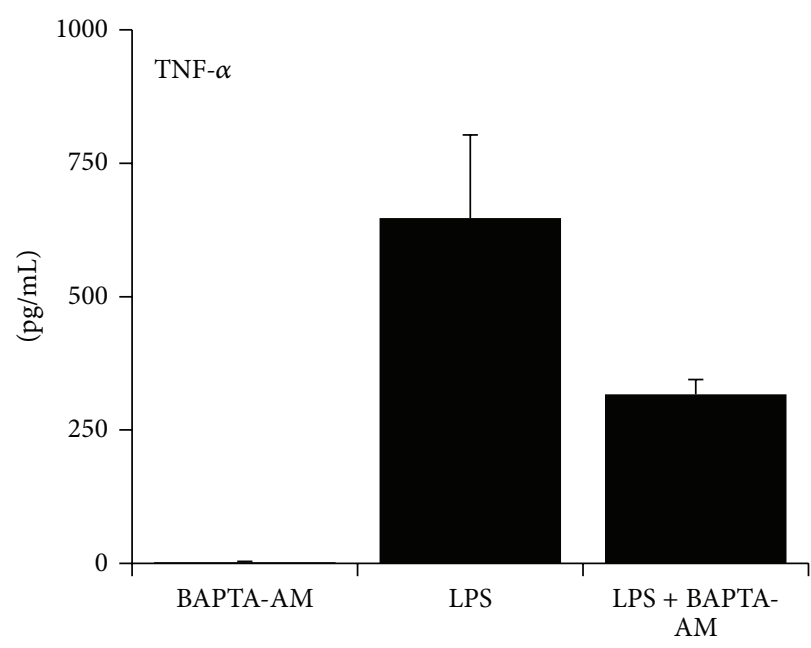

(c)

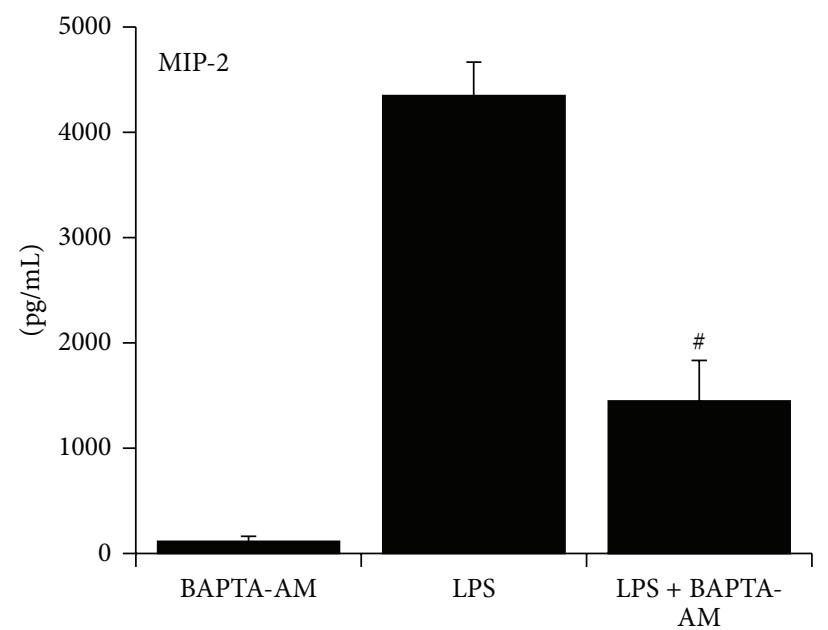

(b)

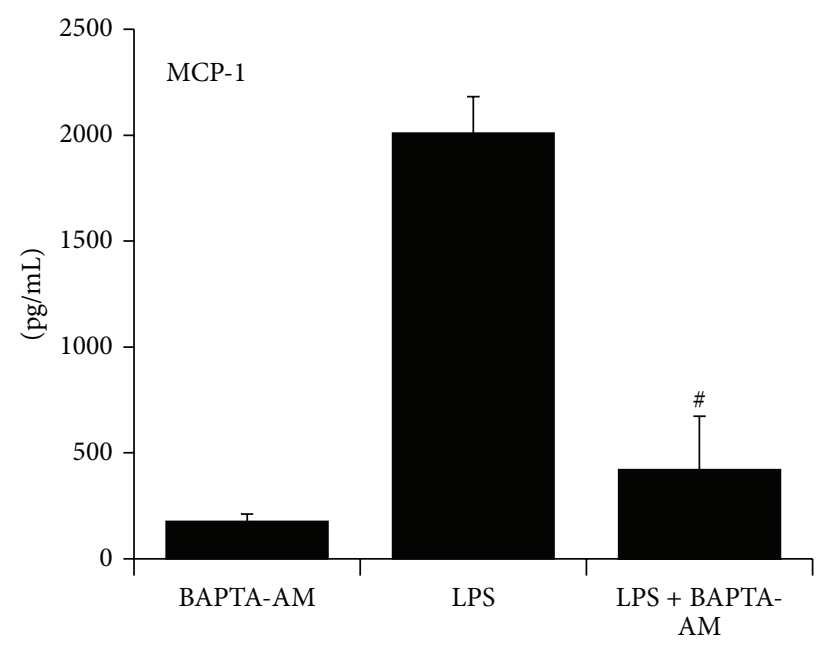

(d)

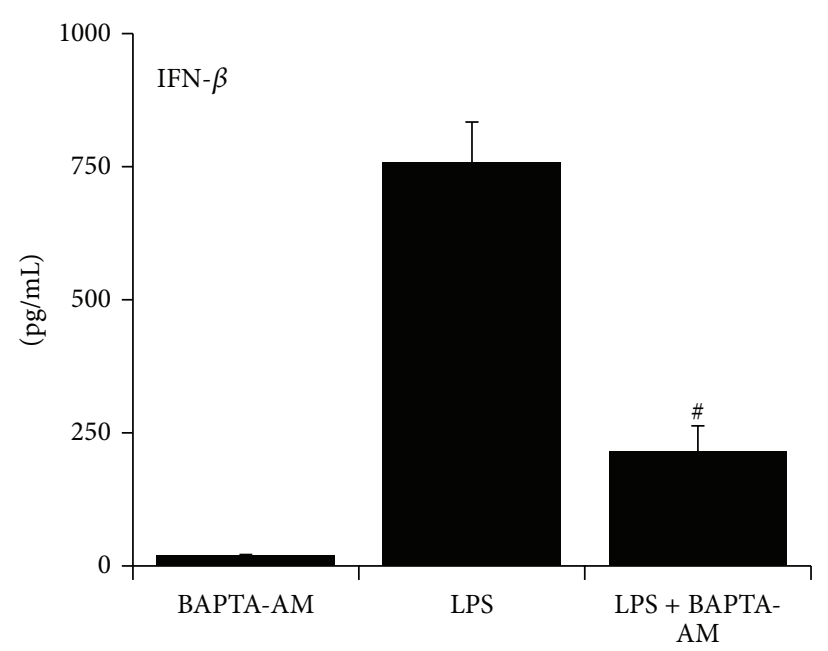

(e)

FIGURE 4: Effects of intracellular $\mathrm{Ca}^{2+}$ depletion (BAPTA-AM pretreatment) on LPS-stimulated cytokine production in aMØs. Isolated aM $\varnothing$ s were stimulated in vitro with BAPTA-AM ( $5 \mu \mathrm{M}$ for $30 \mathrm{~min})$, LPS $(1.5 \mathrm{~g} / \mathrm{mL}$ for $24 \mathrm{hrs})$, or LPS in combination with preceding BAPTA-AM (LPS + BAPTA-AM). Cytokines produced were assessed by ELISA (CINC-1, MIP-2, MCP-1, and INF- $\beta$ ) or cytotoxicity bioassay (TNF- $\alpha$ ). ${ }^{\#} P<0.05$ LPS versus LPS + BAPTA AM. 


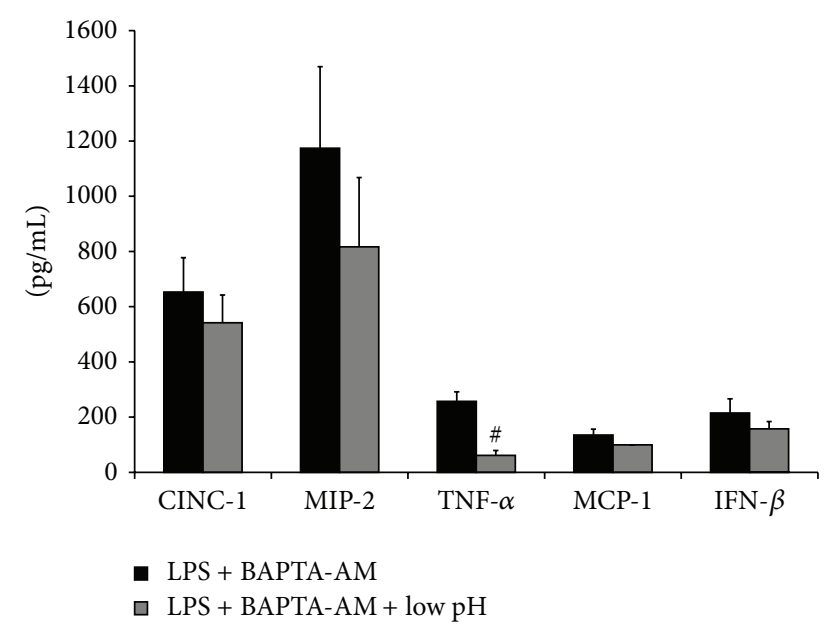

FIGURE 5: Effects of low $\mathrm{pH}$ stress on LPS-stimulated cytokine production in $\mathrm{Ca}^{2+}$-depleted (BAPTA-AM pretreatment) aMØs. Isolated aMØs were exposed to LPS and BAPTA-AM alone (LPS + BAPTA-AM) or in combination with low $\mathrm{pH}$ stress (LPS + BAPTA$\mathrm{AM}+\mathrm{pH}$ ). Cytokines produced were assessed by ELISA (CINC-1, MIP-2, MCP-1, and INF- $\beta$ ) or cytotoxicity bioassay (TNF- $\alpha$ ). ${ }^{\#} P<$ 0.05 LPS + BAPTA-AM versus LPS + BAPTA-AM + pH.

$\mathrm{pH}$ stress exposure of aMØs and identify direct changes in LPS- and LTA-mediated cytokine production.

Our primary findings demonstrated dramatic inhibition of proinflammatory cytokine secretion (i.e., CINC-1, MIP-2, TNF- $\alpha$, and MCP-1) by aM $\varnothing$ s exposed to a low $\mathrm{pH}$ stress. The model used in our experiment was specifically designed to achieve a level of acid exposure to induce the highest level of low $\mathrm{pH}$ stress without a decrease in cell viability. Our preliminary work on establishing cell integrity ensured that the reduced cytokine levels were not a result of changes in $\mathrm{aM} \emptyset \mathrm{s}$ number but rather reflected a true alteration in aMØs signaling. The profound reduction in cytokine levels induced by low $\mathrm{pH}$ stress would be anticipated to negatively impact the aMØs sentinel response to bacterial infection. Our in vivo animal data supports this hypothesis demonstrating suppression of both E. coli and S. pneumoniae bacterial clearance (Figure 8).

As an early surveillance mechanism to detect infection, TLRs recognize specific microbial components or PAMPs. TLR2, which is activated by LTA, is a heterodimer in conjunction with TLR1 and TLR6 [21-23]. Other moieties reported to be recognized by TLR2 are lipoproteins, mycobacterial lipoarabinomannan [24], and rare lipopolysaccharide species [25]. On the other hand, TLR4, which principally acts as a homodimer, is important for recognition of LPS [22]. TLR4 has also been reported to recognize viral proteins $[26,27]$ and several damage-associated molecular patterns (DAMPs) which are products of tissue injury. DAMPs include ligands such as HMGB1, calgranulins, heat shock protein B8 [28], fibrinogen [29], and breakdown products of heparan sulfate polysaccharides [30]. Four adaptor proteins mediate TLRs signaling, and their differential recruitment partially affords pathogen response specificity; the adaptor proteins include MyD88, TRIF (toll-receptor-associated activator of interferon), MAL (MyD88 adapter-like), and TRAM (TRIF-related adapter molecule) [31]. Both TLR2 and TLR4 utilize MyD88 and are the prototypic pathway for TLRs signaling. Recruitment of MyD88 initiates a cascade involving sequential recruitment/activation of IRAK4 (IL-1R-associated kinase 4), IRAK1, tumor-necrosis-factorreceptor-associated factor 6 (TRAF6), and TAK1/TAB1/2/3. Ultimately, three important, well-characterized pathways are activated: nuclear factor- $(\mathrm{NF}-\kappa \mathrm{B})$ [32], mitogen-activated protein kinases (MAP) [33], and phosphoinositide 3-kinases (PI3K) [34]. These distinct pathways result in induction of transcription, mRNA stabilization, and translation of a wide variety of proinflammatory cytokines and chemokines important for bactericidal activity and chemotaxis/recruitment of other immune competent cells [35-37]. TLR4, however, in addition to utilizing MyD88 pathway also utilizes MyD88-independent pathway, recruiting the adaptor protein TRIF/TRAM, leading to activation of interferon regulatory factor 3 (IRF3) and resulting in induction of IFN- $\beta$ [38]. Consistent with previously reported data, our results demonstrated a robust LTA- and LPS-mediated induction of proinflammatory cytokines. Exposure to low $\mathrm{pH}$ stress dramatically inhibited LPS- and LTA-mediated CINC1 , MIP-2, TNF- $\alpha$, and MCP-1 levels (Figures 1 and 2), as well as a parallel inhibition of LPS-mediated IFN- $\beta$ levels (Figure 1(e)). Although the exact mechanism is unclear, this suggests that low $\mathrm{pH}$ stress may act upstream in the intracellular signaling involved in the MyD88 and TRIF pathways, possibly involving receptor binding and/or initial adaptor protein association.

Cytosolic $\mathrm{Ca}^{2+}$ is a ubiquitous second messenger important in many intracellular processes including induction of key transcriptional processes [39]. TLR2 and TLR4 ligand stimulation, in part, utilizes $\mathrm{Ca}^{2+}$ to generate increased cytokine production. The mechanism of $\mathrm{Ca}^{2+}$ flux continues to be investigated, but a mechanism that has been suggested involves receptor ligand binding causing receptor phosphorylation by c-Src $[40,41]$. This leads to activation of PI3K and phospholipase $\mathrm{C} \gamma 2$ (PLC $\gamma 2$ ), affecting release of intracellular $\mathrm{Ca}^{2+}$ store through IP3R activation in the endoplasmic reticulum [41]. The exact $\mathrm{Ca}^{2+}$-dependent step affecting NF- $\kappa$ B activity is still unclear, but several potential candidates may include traditional $\mathrm{Ca}^{2+}$-sensitive protein kinases such as protein kinase $\mathrm{C} \alpha(\mathrm{PKC} \alpha), \operatorname{PKC} \beta, \operatorname{PKC} \gamma$, and calmodulin-dependent kinases that have been shown to modulate NF- $\kappa \mathrm{B}$ activity $[42,43]$. Cytosolic changes in $\left[\mathrm{Ca}^{2+}\right]_{\mathrm{i}}$ are also required for optimal TLR4 trafficking to the endosomes and the phosphorylation/nuclear localization of IRF3 [44]. Our data further confirms the essential role of $\mathrm{Ca}^{2+}$ in TLR2 and TLR4 signaling, through demonstration of $\left[\mathrm{Ca}^{2+}\right]_{\mathrm{i}}$ increases in response to LPS and LTA (Figure 3) and reduction in cytokine levels following intracellular $\mathrm{Ca}^{2+}$ depletion (Figures 4-6). By tracking the changes in $\left[\mathrm{Ca}^{2+}\right]_{\mathrm{i}}$ at different time points, we demonstrated the complex nature of the cytosolic $\mathrm{Ca}^{2+}$ profile generated by LPS with an early transient single peak followed by low level $\left[\mathrm{Ca}^{2+}\right]_{\mathrm{i}}$ (Figure 3(b)). LTA stimulation, on the other hand, resulted in a biphasic pattern with an early peak followed by return 


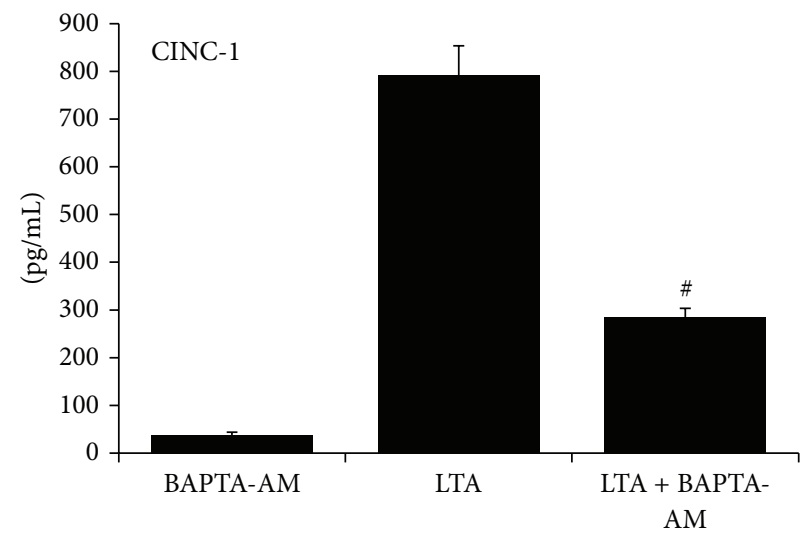

(a)

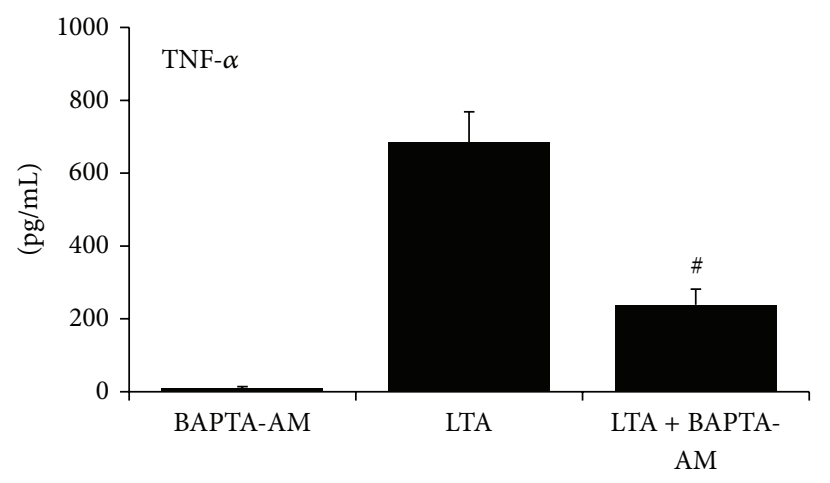

(c)

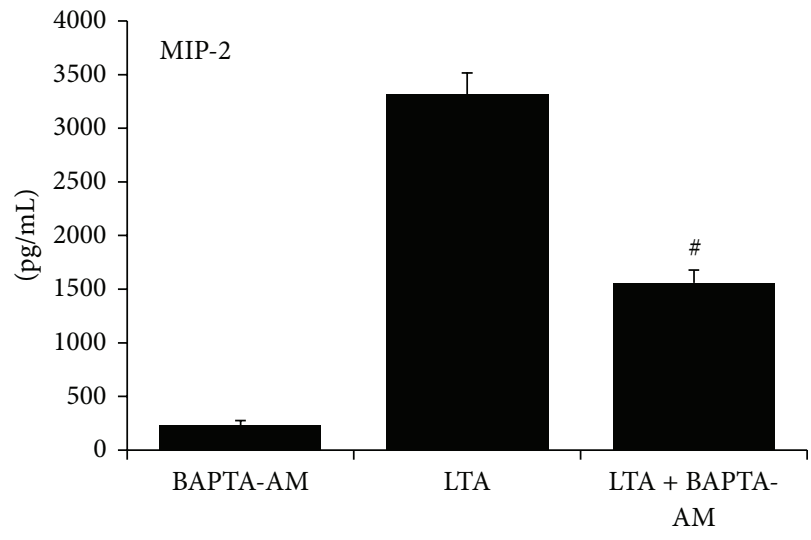

(b)

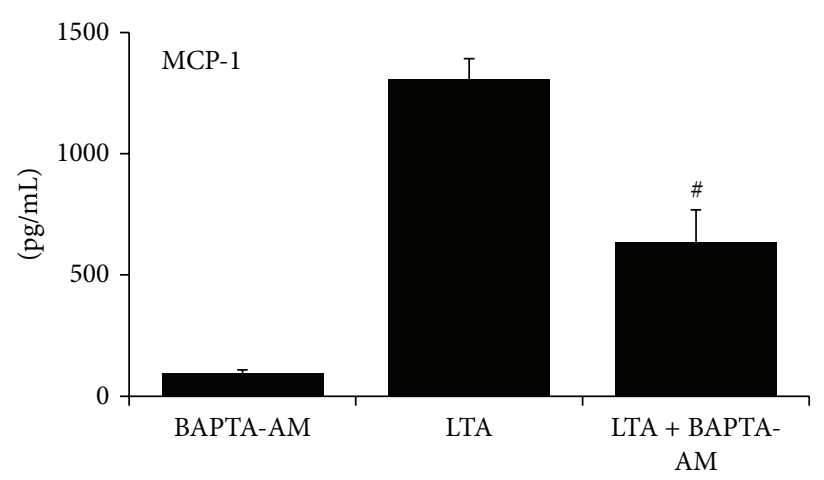

(d)

FIGURE 6: Effects of intracellular $\mathrm{Ca}^{2+}$ depletion (BAPTA-AM pretreatment) on LTA-stimulated cytokine production in aMØs. Isolated aMØs were stimulated in vitro with BAPTA-AM ( $5 \mu \mathrm{M}$ for $30 \mathrm{~min})$, LTA $(30 \mathrm{mg} / \mathrm{mL}$ for $24 \mathrm{hrs})$, or LTA in combination with preceding BAPTA-AM treatment (LTA + BAPTA-AM). Cytokines produced were assessed by ELISA (CINC-1, MIP-2, and MCP-1) or cytotoxicity bioassay (TNF- $\alpha$ ). ${ }^{*} P<0.05$ LTA versus LTA + BAPTA-AM.

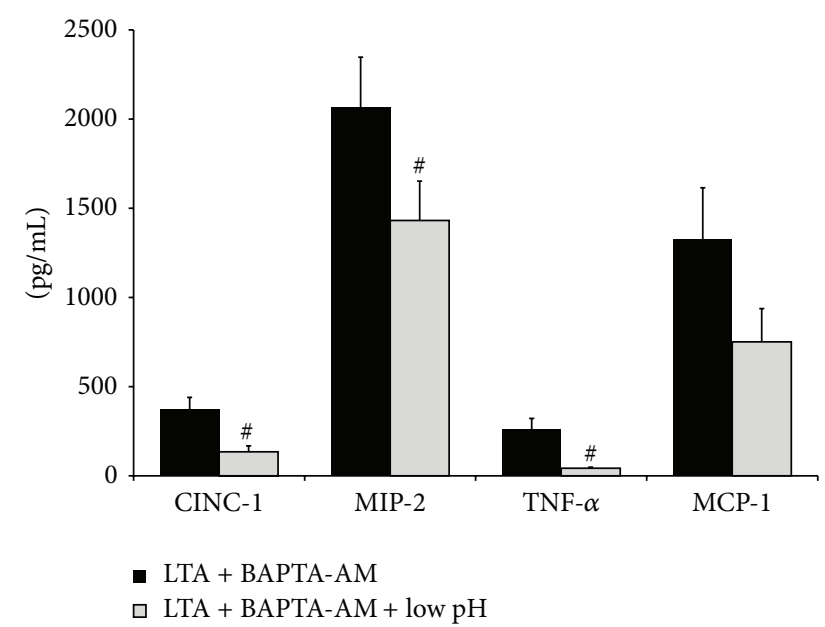

Figure 7: Effects of low $\mathrm{pH}$ stress on LTA-stimulated cytokine production in $\mathrm{Ca}^{2+}$-depleted alveolar macrophages (BAPTA-AM pretreatment). Isolated aM $\emptyset$ s were exposed to LTA and BAPTA-AM alone (LTA + BAPTA-AM) or in combination with low $\mathrm{pH}$ stress $(\mathrm{LTA}+\mathrm{BAPTA}-\mathrm{AM}+\mathrm{pH})$. Cytokines produced were assessed by ELISA (CINC-1, MIP-2, and MCP-1) or cytotoxicity bioassay (TNF$\alpha) .{ }^{\#} P<0.05$ LTA + BAPTA-AM versus LTA + BAPTA-AM + pH. to baseline and a secondary peak at a later time point (Figure 3(c)). Overall LPS, in contrast to LTA, resulted in a less robust $\mathrm{Ca}^{2+}$ response. The nature of this difference is unclear; however, this short-lived but biologically important $\mathrm{Ca}^{2+}$ response to LPS is consistent with other reported literature on LPS-stimulated $\mathrm{Ca}^{2+}$ response, demonstrating only transient increases in $\mathrm{Ca}^{2+}$, predominantly in the range of 50-150 nM [45-47]. Combined exposures of LPS or LTA with low $\mathrm{pH}$ stress did not result in a simple summation of $\mathrm{Ca}^{2+}$ profile but modified LPS- and LTA-induced $\mathrm{Ca}^{2+}$ profiles in distinct patterns. In LPS-stimulated cells, low $\mathrm{pH}$ stress tended to generally increase $\left[\mathrm{Ca}^{2+}\right]_{\mathrm{i}}$ (Figure 3(b)). In contrast, low $\mathrm{pH}$ stress suppressed $\left[\mathrm{Ca}^{2+}\right]_{\mathrm{i}}$ in the early phase of LTA stimulation but augmented it at a later phase (Figure 3(c)).

To further investigate the role of $\mathrm{Ca}^{2+}$, we also utilized BAPTA-AM to effectively sequester free intracellular $\mathrm{Ca}^{2+}$. BAPTA-AM at the concentration used in our experiments has been used by different laboratories as a $\mathrm{Ca}^{2+}$ selective sequestrant $[19,48-50]$. Although other non-Ca ${ }^{2+}$ dependent mechanisms can potentially be altered by BAPTA$\mathrm{AM}$, it appears to have a very high selectivity over other 


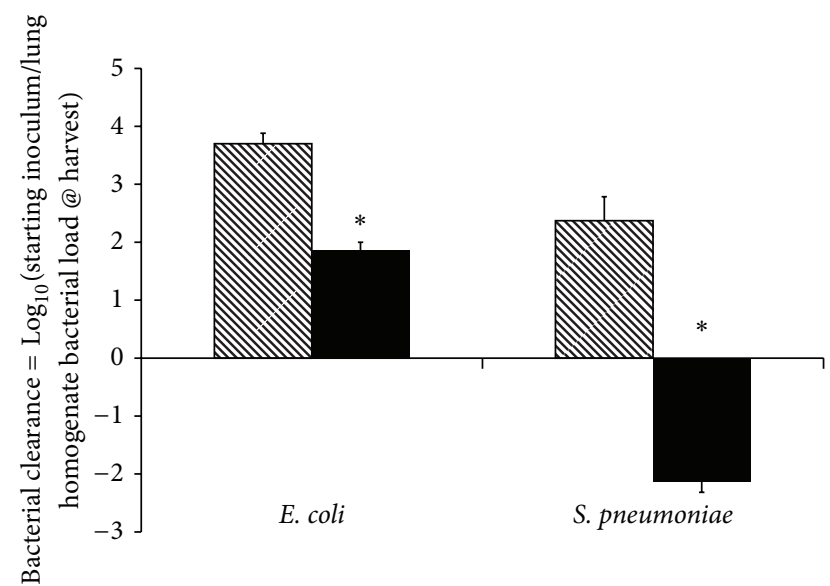

N Pulmonary bacterial challenge

- Pulmonary bacterial challenge + low $\mathrm{pH}$ stress

FIGURE 8: Effect of acid aspiration (low pH stress) on bacterial clearance in vivo was assessed using a mouse model of pulmonary bacterial infection. Pulmonary bacterial challenge was initiated using intratracheal administration of known titers (starting inoculum) of E. coli (left panel) or S. pneumoniae (right panel). Acid aspiration was modelled using intratracheal administration of acidified saline ( $\mathrm{pH}$ 1.25) prior to bacterial challenge (pulmonary bacterial challenge + low $\mathrm{pH}$ stress). Lung homogenates were prepared $24 \mathrm{hr}$ after intratracheal bacterial challenge and bacterial load quantified. ${ }^{*} P<0.05$ Bacterial pulmonary challenge alone versus bacterial pulmonary challenge + low $\mathrm{pH}$ stress. ${ }^{*} \mathrm{P}<0.05$ versus bacterial inoculation alone.

bivalent cations, and its biologic activities have been linked predominantly to its ability to sequester $\mathrm{Ca}^{2+}[19,48-50]$. Under a $\left[\mathrm{Ca}^{2+}\right]_{\mathrm{i}}$-clamped state (BAPTA-treated cells), low $\mathrm{pH}$ stress failed to modify LPS-mediated production of proinflammatory cytokines (Figure 5) while continuing to suppress LTA-mediated cytokine production (Figure 7). This differential response suggests that the interaction of low $\mathrm{pH}$ stress on LPS/TLR4 and LTA/TLR2 pathways may be distinct with TLR4 involving predominantly $\mathrm{Ca}^{2+}$-dependent mechanisms, while that of TLR2 may involve $\mathrm{Ca}^{2+}$-independent mechanisms.

In summary, our findings demonstrate a strong suppressive direct effect of low $\mathrm{pH}$ stress on the ability of aMØs to mount an adequate antibacterial proinflammatory response following TLR2 and TLR4 activation. The site of action of the low pH stress appears to involve both the MyD88 and TRIF pathways. $\mathrm{Ca}^{2+}$ is an essential component for efficient elaboration of LPS- and LTA-mediated cytokine response but plays a differential role in mediating the suppressive effects of low $\mathrm{pH}$ stress. Changes in $\left[\mathrm{Ca}^{2+}\right]_{\mathrm{i}}$ appear to be required for LPS-stimulated responses but are less important for the LTAmediated response. The mechanism for this differential role of cytosolic $\mathrm{Ca}^{2+}$ signaling needs further investigation, but the data presented in this study suggest that the mechanistic effect of low $\mathrm{pH}$ stress cannot be generalized across the various TLRs signaling cascades. These findings further our understanding of aMØs dysfunction following acute gastric aspiration and the role of this resident sentinel lung cell in the increased susceptibility to bacterial infection.

\section{References}

[1] P. E. Marik, "Aspiration pneumonitis and aspiration pneumonia," The New England Journal of Medicine, vol. 344, no. 9, pp. 665-671, 2001.

[2] K. Raghavendran, J. Nemzek, L. M. Napolitano, and P. R. Knight, "Aspiration-induced lung injury," Critical Care Medicine, vol. 39, no. 4, pp. 818-826, 2011.

[3] T. P. Kennedy, K. J. Johnson, R. G. Kunkel, P. A. Ward, P. R. Knight, and J. S. Finch, "Acute acid aspiration lung injury in the rat: biphasic pathogenesis," Anesthesia \& Analgesia, vol. 69, no. 1, pp. 87-92, 1989.

[4] P. R. Knight, T. Rutter, A. R. Tait, E. Coleman, and K. Johnson, "Pathogenesis of gastric particulate lung injury: a comparison and interaction with acidic pneumonitis," Anesthesia \& Analgesia, vol. 77, no. 4, pp. 754-760, 1993.

[5] B. A. Davidson, P. R. Knight, J. D. Helinski, N. D. Nader, T. P. Shanley, and K. J. Johnson, "The role of tumor necrosis factor$\alpha$ in the pathogenesis of aspiration pneumonitis in rats," Anesthesiology, vol. 91, no. 2, pp. 486-499, 1999.

[6] P. R. Knight, B. A. Davidson, N. D. Nader et al., "Progressive, severe lung injury secondary to the interaction of insults in gastric aspiration," Experimental Lung Research, vol. 30, no. 7, pp. 535-557, 2004.

[7] A. T. Rotta, K. T. Shiley, B. A. Davidson, J. D. Helinski, T. A. Russo, and P. R. Knight, "Gastric acid and particulate aspiration injury inhibits pulmonary bacterial clearance," Critical Care Medicine, vol. 32, no. 3, pp. 747-754, 2004.

[8] N. W. J. Schröder, S. Morath, C. Alexander et al., "Lipoteichoic acid (LTA) of Streptococcus pneumoniae and Staphylococcus aureus activates immune cells via toll-like receptor (TLR)-2, lipopolysaccharide-binding protein (LBP), and CD14, whereas TLR-4 and MD-2 are not involved," The Journal of Biological Chemistry, vol. 278, no. 18, pp. 15587-15594, 2003.

[9] W. Huang, S. Ghisletti, V. Perissi, M. G. Rosenfeld, and C. K. Glass, "Transcriptional integration of TLR2 and TLR4 signaling at the NCoR derepression checkpoint," Molecular Cell, vol. 35, no. 1, pp. 48-57, 2009.

[10] M. Illario, M. L. Giardino-Torchia, U. Sankar et al., "Calmodulin-dependent kinase IV links toll-like receptor 4 signaling with survival pathway of activated dendritic cells," Blood, vol. 111, no. 2, pp. 723-731, 2008.

[11] B. H. Segal, B. A. Davidson, A. D. Hutson et al., "Acid aspirationinduced lung inflammation and injury are exacerbated in NADPH oxidase-deficient mice," American Journal of Physiology, vol. 292, no. 3, pp. L760-L768, 2007.

[12] R. E. Bishop, "Fundamentals of endotoxin structure and function," Contributions to Microbiology, vol. 12, pp. 1-27, 2005.

[13] C. Raetz and C. Whitfield, "Lipopolysaccharide endotoxins," Annual Review of Biochemistry, vol. 71, pp. 635-700, 2002.

[14] B. Opitz, N. W. J. Schröder, I. Spreitzer et al., "Toll-like receptor2 mediates treponema glycolipid and lipoteichoic acid-induced NF- $\kappa$ B translocation," The Journal of Biological Chemistry, vol. 276, no. 25, pp. 22041-22047, 2001.

[15] M. Trianiafilou, M. Manukyan, A. Mackie et al., "Lipoteichoic acid and toll-like receptor 2 internalization and targeting to the Golgi are lipid raft-dependent," The Journal of Biological Chemistry, vol. 279, no. 39, pp. 40882-40889, 2004. 
[16] K. Raddassi, B. Berthon, J.-F. Petit, and G. Lemaire, "Role of calcium in the activation of mouse peritoneal macrophages: induction of NO synthase by calcium ionophores and thapsigargin," Cellular Immunology, vol. 153, no. 2, pp. 443-455, 1994.

[17] C. L. Young, A. Feierstein, and F. S. Southwick, "Calcium regulation of actin filament capping and monomer binding by macrophage capping protein," The Journal of Biological Chemistry, vol. 269, no. 19, pp. 13997-14002, 1994.

[18] D. Lai, M. Wan, J. Wu et al., "Induction of TLR4-target genes entails calcium/calmodulin-dependent regulation of chromatin remodeling," Proceedings of the National Academy of Sciences of the United States of America, vol. 106, no. 4, pp. 1169-1174, 2009.

[19] D. M. Brown, K. Donaldson, P. J. Borm et al., "Calcium and ROS-mediated activation of transcription factors and TNF- $\alpha$ cytokine gene expression in macrophages exposed to ultrafine particles," American Journal of Physiology, vol. 286, no. 2, pp. L344-L353, 2004.

[20] K. Raghavendran, B. A. Davidson, J. C. Huebschmann et al., "Superimposed gastric aspiration increases the severity of inflammation and permeability injury in a rat model of lung contusion," Journal of Surgical Research, vol. 155, no. 2, pp. 273282, 2009.

[21] R. Schwandner, R. Dziarski, H. Wesche, M. Rothe, and C. J. Kirschning, "Peptidoglycan- and lipoteichoic acid-induced cell activation is mediated by toll-like receptor 2," The Journal of Biological Chemistry, vol. 274, no. 25, pp. 17406-17409, 1999.

[22] O. Takeuchi, K. Hoshino, T. Kawai et al., "Differential roles of TLR2 and TLR4 in recognition of gram-negative and grampositive bacterial cell wall components," Immunity, vol. 11, no. 4, pp. 443-451, 1999.

[23] A. Yoshimura, E. Lien, R. R. Ingalls, E. Tuomanen, R. Dziarski, and D. Golenbock, "Cutting edge: recognition of gram-positive bacterial cell wall components by the innate immune system occurs via toll-like receptor 2," The Journal of Immunology, vol. 163, no. 1, pp. 1-5, 1999.

[24] R. I. Tapping and P. S. Tobias, "Mycobacterial lipoarabinomannan mediates physical interactions between TLR1 and TLR2 to induce signaling," Journal of Endotoxin Research, vol. 9, no. 4, pp. 264-268, 2003.

[25] M. Martin, J. Katz, S. N. Vogel, and S. M. Michalek, "Differential induction of endotoxin tolerance by lipopolysaccharides derived from Porphyromonas gingivalis and Escherichia coli," The Journal of Immunology, vol. 167, no. 9, pp. 5278-5285, 2001.

[26] E. A. Kurt-Jones, L. Popova, L. Kwinn et al., "Pattern recognition receptors TLR4 and CD14 mediate response to respiratory syncytial virus," Nature Immunology, vol. 1, no. 5, pp. 398-401, 2000.

[27] J. C. Rassa, J. L. Meyers, Y. Zhang, R. Kudaravalli, and S. R. Ross, "Murine retroviruses activate B cells via interaction with tolllike receptor 4," Proceedings of the National Academy of Sciences of the United States of America, vol. 99, no. 4, pp. 2281-2286, 2002.

[28] M. F. Roelofs, W. C. Boelens, L. A. B. Joosten et al., "Identification of small heat shock protein B8 (HSP22) as a novel TLR4 ligand and potential involvement in the pathogenesis of rheumatoid arthritis," The Journal of Immunology, vol. 176, no. 11, pp. 7021-7027, 2006.

[29] S. T. Smiley, J. A. King, and W. W. Hancock, "Fibrinogen stimulates macrophage chemokine secretion through toll-like receptor 4," The Journal of Immunology, vol. 167, no. 5, pp. 28872894, 2001.
[30] G. B. Johnson, G. J. Brunn, Y. Kodaira, and J. L. Platt, "Receptormediated monitoring of tissue well-being via detection of soluble heparan sulfate by toll-like receptor 4," The Journal of Immunology, vol. 168, no. 10, pp. 5233-5239, 2002.

[31] L. A. J. O’Neill and A. G. Bowie, “The family of five: TIR-domain-containing adaptors in toll-like receptor signalling," Nature Reviews Immunology, vol. 7, no. 5, pp. 353-364, 2007.

[32] F. X. Zhang, C. J. Kirschning, R. Mancinelli et al., "Bacterial lipopolysaccharide activates nuclear factor- $\kappa \mathrm{B}$ through interleukin-1 signaling mediators in cultured human dermal endothelial cells and mononuclear phagocytes," The Journal of Biological Chemistry, vol. 274, no. 12, pp. 7611-7614, 1999.

[33] C. Ropert, I. C. Almeida, M. Closel et al., "Requirement of mitogen-activated protein kinases and $\mathrm{I} \kappa \mathrm{B}$ phosphorylation for induction of proinflammatory cytokines synthesis by macrophages indicates functional similarity of receptors triggered by glycosylphosphatidylinositol anchors from parasitic protozoa and bacterial lipopolysaccharide," The Journal of Immunology, vol. 166, no. 5, pp. 3423-3431, 2001.

[34] P. G. Arndt, N. Suzuki, N. J. Avdi, K. C. Malcolm, and G. S. Worthen, "Lipopolysaccharide-induced c-Jun $\mathrm{NH}_{2}$-terminal kinase activation in human neutrophils: role of phosphatidylinositol 3-kinase and Syk-mediated pathways," The Journal of Biological Chemistry, vol. 279, no. 12, pp. 10883-10891, 2004.

[35] Z.-M. Wang, C. Liu, and R. Dziarski, "Chemokines are the main proinflammatory mediators in human monocytes activated by Staphylococcus aureus, peptidoglycan, and endotoxin," The Journal of Biological Chemistry, vol. 275, no. 27, pp. 2026020267, 2000.

[36] K. M. Kopydlowski, C. A. Salkowski, M. J. Cody et al., "Regulation of macrophage chemokine expression by lipopolysaccharide in vitro and in vivo," The Journal of Immunology, vol. 163, no. 3, pp. 1537-1544, 1999.

[37] C. A. Salkowski, G. Detore, A. Franks, M. C. Falk, and S. N. Vogel, "Pulmonary and hepatic gene expression following cecal ligation and puncture: monophosphoryl lipid a prophylaxis attenuates sepsis-induced cytokine and chemokine expression and neutrophil infiltration," Infection and Immunity, vol. 66, no. 8, pp. 3569-3578, 1998.

[38] E. M. Pålsson-McDermott and L. A. J. O’Neill, “Signal transduction by the lipopolysaccharide receptor, toll-like receptor-4," Immunology, vol. 113, no. 2, pp. 153-162, 2004.

[39] B. Mellström, M. Savignac, R. Gomez-Villafuertes, and J. R. Naranjo, " $\mathrm{Ca}^{2+}$-operated transcriptional networks: molecular mechanisms and in vivo models," Physiological Reviews, vol. 88, no. 2, pp. 421-449, 2008.

[40] G. Soong, B. Reddy, S. Sokol, R. Adamo, and A. Prince, "TLR2 is mobilized into an apical lipid raft receptor complex to signal infection in airway epithelial cells," The Journal of Clinical Investigation, vol. 113, no. 10, pp. 1482-1489, 2004.

[41] J. Chun and A. Prince, "Activation of $\mathrm{Ca}^{2+}$-dependent signaling by TLR2," The Journal of Immunology, vol. 177, no. 2, pp. 13301337, 2006.

[42] A. M. F. Liu and Y. H. Wong, "Activation of nuclear factor $\kappa$ B by somatostatin type 2 receptor in pancreatic acinar AR42J cells involves $\mathrm{G} \alpha 14$ and multiple signaling components," The Journal of Biological Chemistry, vol. 280, no. 41, pp. 34617-34625, 2005.

[43] A. M. F. Liu and Y. H. Wong, "G16-mediated activation of nuclear factor $\kappa \mathrm{B}$ by the adenosine A1 receptor involves c-Src, protein kinase C, and ERK signaling," The Journal of Biological Chemistry, vol. 279, no. 51, pp. 53196-53204, 2004. 
[44] C.-Y. Chiang, V. Veckman, K. Limmer, and M. David, "Phospholipase $C \gamma-2$ and intracellular calcium are required for lipopolysaccharide-induced toll-like receptor 4 (TLR4) endocytosis and interferon regulatory factor 3 (IRF3) activation," The Journal of Biological Chemistry, vol. 287, no. 6, pp. 3704-3709, 2012.

[45] R. S. Hotchkiss, W. M. Bowling, I. E. Karl, D. F. Osborne, and M. Wayne, "Calcium antagonists inhibit oxidative burst and nitrite formation in lipopolysaccharide-stimulated rat peritoneal macrophages," Shock, vol. 8, no. 3, pp. 170-178, 1997.

[46] M. D. Wheeler and R. G. Thurman, "Production of superoxide and TNF- $\alpha$ from alveolar macrophages is blunted by glycine," American Journal of Physiology, vol. 277, no. 5, part 1, pp. L952L959, 1999.

[47] J. Sun, Z. Q. Zhou, R. Lv, W. Y. Li, and J. G. Xu, "Ketamine inhibits LPS-induced calcium elevation and NF-kappa B activation in monocytes," Inflammation Research, vol. 53, no. 7, pp. 304-308, 2004.

[48] R. Y. Tsien, "New calcium indicators and buffers with high selectivity against magnesium and protons: design, synthesis, and properties of prototype structures," Biochemistry, vol. 19, no. 11, pp. 2396-2404, 1980.

[49] S. Zhou, X. Yuan, X. Zhang et al., "BAPTA-AM, an intracellular calcium chelator, inhibits RANKL-induced bone marrow macrophages differentiation through MEK/ERK, p38 MAPK and Akt, but not JNK pathways," Cytokine, vol. 52, no. 3, pp. 210214, 2010.

[50] K. M. Abdel-Hamid and M. Tymianski, "Mechanisms and effects of intracellular calcium buffering on neuronal survival in organotopic hippocampal cultures exposed to anoxia/aglycemia or to excitotoxins," The Journal of Neuroscience, vol. 17, no. 10, pp. 3538-3553, 1997. 


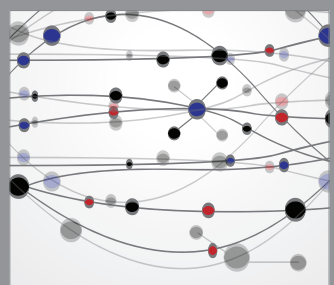

The Scientific World Journal
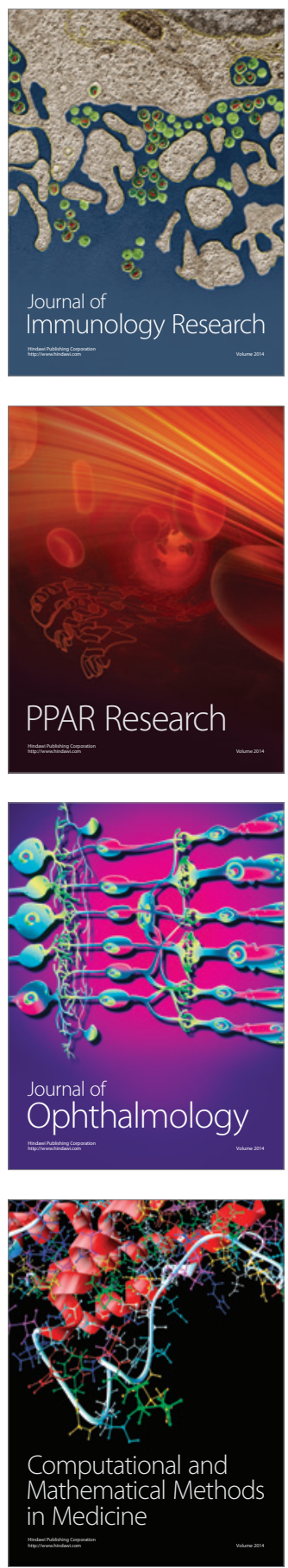

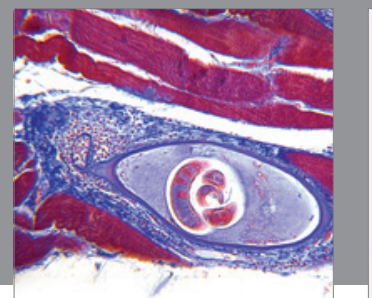

Gastroenterology

Research and Practice
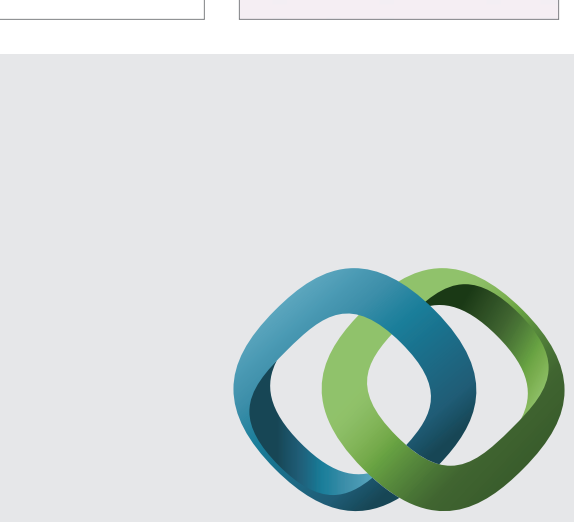

\section{Hindawi}

Submit your manuscripts at

http://www.hindawi.com
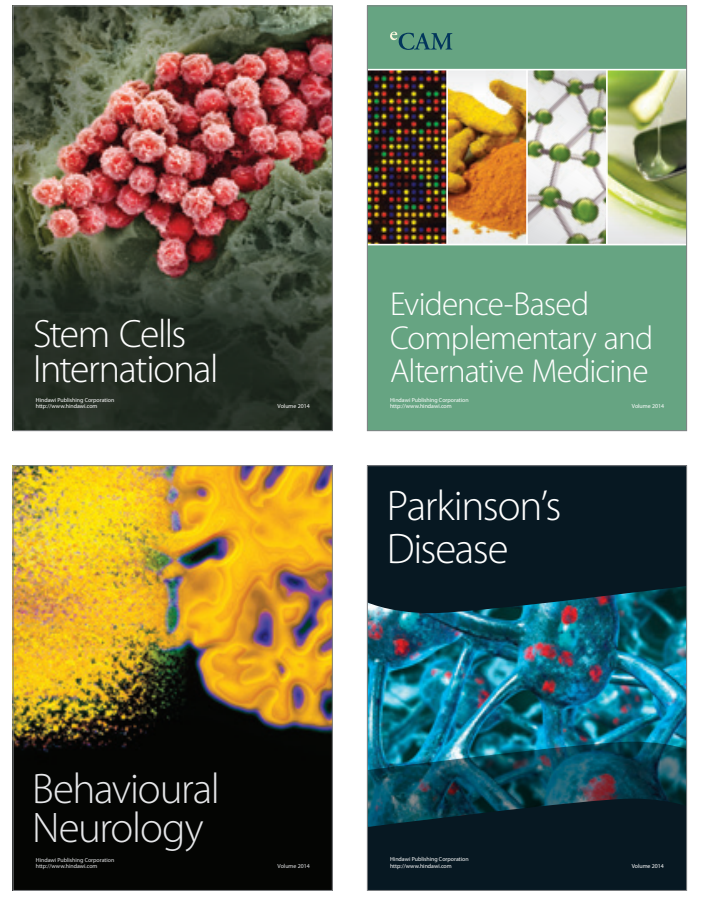
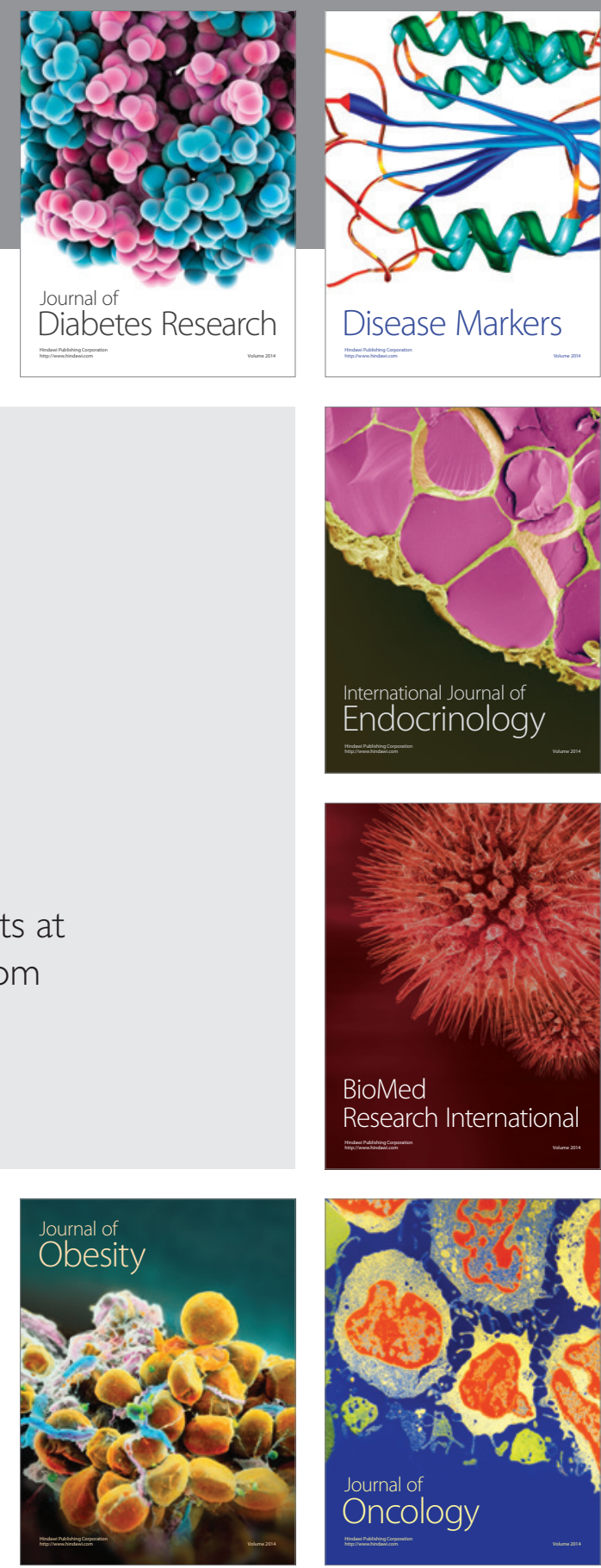

Disease Markers
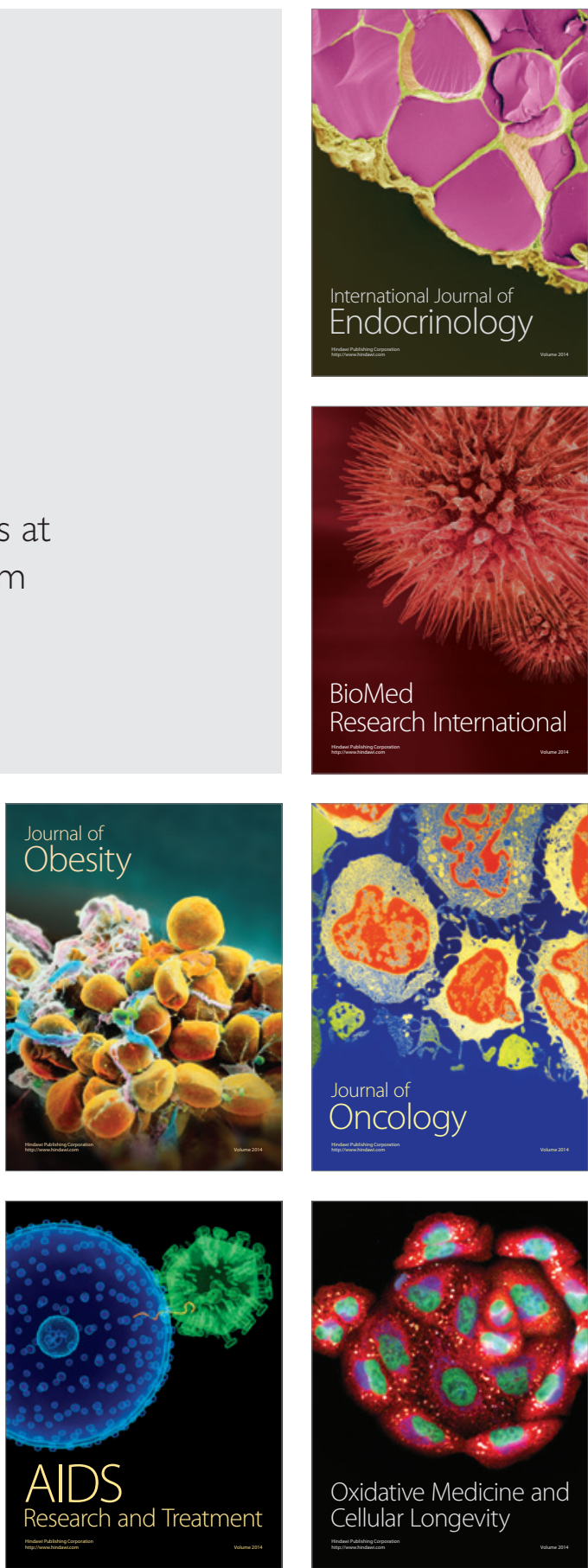